\title{
WATER DEMAND, SUPPLY, AND QUALITY IN THE UNITED STATES: SUSTAINABILITY OF WATER USES
}

\author{
P.F. RICCI \\ Department of Environment Science, University of San Francisco, San Francisco, CA, USA.
}

\section{ABSTRACT}

The purpose of this paper is to develop, from a very wide variety of public data, a synthesis of the status of water supply, demand, and quality for the United States from 1985 to the present, in an effort to obtain a dynamic baseline for assessing the sustainability of multiple water uses. Although the United States has relatively ample supplies of water, it is likely that deficits will occur in areas with increasing population and economic development. Variations in population, industrial, and agricultural production are driven by internal and external factors among which water probably causes the largest disruptions because of the inability to adapt to those changes. Climate changes due to global and regional warming trends also have major impacts on water availability and quality, although they are less sudden than structural changes in the economy. To help frame a baseline from which those changes can be measured to assess its sustainability for the population of the United States, we summarize the most salient findings about the status of US water supply, demand, and quality at the level of the water resource regions, and states over a period of approximately 20 years. Our synthesis of the data collected by the US agencies indicates that water quality is improving and the supply of water for the United States is generally good. However, shortages of water predicted from linear extrapolations of past trends, appear principally to affect the western water resource regions. Using US Census Bureau 'high population' forecasts, water shortages may be felt earlier and in more water resource regions than previously expected. These conclusions implicitly take into account changes in the US economy during the mid-eighties but do not account for: regional-scale climate, legal low-flow requirements, or other non-routine occurrences.

Keywords: demand, supply, sustainability, water quality, water quality index, water uses.

\section{INTRODUCTION}

Water is an essential factor of production; it harbors and supports life. Yet, some of the life it harbors can cause illness or death; droughts and floods cause casualties, environmental and property damage, and dislocate the economy. Some changes, such as in the frequency and intensity of floods and droughts, can create a great variety of adverse impacts on society and the natural environment. When coupled to concomitant changes in population growth, these increase the vulnerability of those not previously at risk and exacerbate the vulnerability of those who already are at risk [1,2].

The central purpose of this paper is to establish a historical, dynamic baseline for water supply, demand, and quality, beginning in 1985 and ending in 2002, for the United States. We study fresh and saline, surface and ground waters, but focus on fresh surface and ground water availability and the demands by such specific sectors of the economy as agriculture, livestock, thermoelectric power generation, industrial, public, and commercial users, as well as water quality at a relatively high level of resolution, but a level of detail that is consistent for the Nation as a whole. Water demands and allocations are affected by multiple and diverse factors and events. Adverse events can - and often do - occur at different points in time and space and be of very different duration. Those events, such as droughts or floods, may have diverse trends, cycles, and seasonalities. Even when demand is met efficiently, water policy must confront wasteful uses [3, 4]. Moreover, indirect changes, such as changes to the quantity of water embodied in foodstuff, affect sectoral water demands. The factors that affect water quality, availability, and use include legal requirements, such as low-flow requirements 
and water use efficiency, socio-economic and health ones. Environmental events, such as toxic spills, also affect water demand, allocations, and quality and thus affect the social and economic well-being of either a community or a region.

In this paper we give a qualitative, unified synthesis and perspective on the quantities of water supplied and demanded at the level of detail of the water resource region, WRR, (a US Geological Survey definition of homogeneous water basins), and water quality summaries at the state level. We thus complement, augment, and corroborate several contributions from the literature and fill a gap in the information by providing an integrated view of water supply, demand, and quality that so far appears to have been missing. To our knowledge, this integration of water quality supply, demand, and quantity at this level of detail, namely the water resource region and state levels, and for several sectors of the economy, has not been reported elsewhere.

\subsection{The Context}

On average, from 1900 to 1990, the population of the Unites States increased by about $1.2 \%$ per year while water withdrawals increased at a faster rate, approximately $2.4 \%$ per year. Table 1 summarizes population projections for the United States as a whole $[5,6]$.

Americans withdrew, in 1900, 475 GPD (1,798 liters per day) (lpd); but that number has increased to approximately 1,350 GPD (5,110 lpd) in 1990. More recently, in 1995, the United States surface fresh water withdrawals were 324,000 million gallons per day (MGD) $(12,264,734,243,215$ lpd), total ground water withdrawals were 77,500 MGD (293,369,414,768 lpd) and the saline water uses were about 60,800 MGD $(230,153,037,650$ lpd) [7]. The largest water users were irrigation, which used most of the fresh water at 134,000 MGD (507,245,181,664 lpd), and thermal power generation, which used 190,000 MGD (507,245,181,664 lpd) (of which approximately 58,000 MGD $(219,553,884,601 \mathrm{lpd})$ was saline water) [7]. There are remarkable differences in the fate of water withdrawals by different sectors. For instance, a large percentage of the water withdrawn for cooling thermal power plants is quickly returned to the source water body, albeit at a higher temperature and with perhaps added chemicals. In that same year, reclaimed wastewater use was approximately 1,000 MGD (3,785,411,803 lpd). The 1995 overall water withdrawals were $10 \%$ less than the 1980 withdrawals. The five sectors of the economy we use in this work (irrigation, thermoelectric power generation, industrial and commercial users, domestic and public users, and livestock) show a decline in water use from 1980 to 1995 , ranging from 3 to $14 \%$, although the US population increased by approximately $16 \%$ over this period. About 60 million US households are served by urban/storm water systems and about 10.5 million households have non-urban storm water systems [8].

Table 1: Population Projections (adapted from [5, 6]).

\begin{tabular}{cccc}
\hline Year & Lowest series & Middle series & Highest series \\
\hline 2000 & $274,853,000$ & $275,306,000$ & $275,816,000$ \\
2010 & $291,413,000$ & $299,862,000$ & $310,910,000$ \\
2020 & $303,664,000$ & $324,927,000$ & $354,642,000$ \\
2030 & $311,656,000$ & $351,070,000$ & $409,604,000$ \\
2040 & $314,673,000$ & $377,350,000$ & $475,949,000$ \\
2050 & $313,546,000$ & $403,687,000$ & $552,757,000$ \\
\hline
\end{tabular}


The reasons for the changes in water demand include federal legislation (such as the Clean Water Act, 1972; the National Energy Policy Act, 1992, and other federal and state laws) as well as conservation, leak detection and repairs, and pricing policies. The structural changes reflected in past aggregate water projections were the result of the transitions from supply-side management of water to demand-side management and increased users' awareness of the importance and costs of water [9]. Federal laws controlling water pollution caused the technological changes in processes that use water as an input (including cooling towers) and the increased recycling of water. The agricultural sector improved its crop patterns and the delivery of water for irrigation; it also lessened its reliance on ground water because of increased costs of pumped water. At the same time, agricultural patterns shifted from the West of the United Sates to the East $[4,10]$. The number of irrigated areas peaked in 1980, and has been steady from 1985 to 1995 (at about 58 million acres, million ac, or 23,472,278 hectares, ha). In the West, the irrigated acreage was 49 million ac (19,830,028 ha) in 1980, declining to about 45 million ac $(18,211,251 \mathrm{ha})$, while the East has steadily increased from about 2 million ac $(809,389$ ha) in 1950 to about 12 million ac (4,856,333 ha) in 1995 [9]. Domestic water uses have been approximately constant from 1980 to 1995 [9].

The use of water by the five sectors of the economy we consider is characterized by complex and inter-dependent relationships that determine the temporal equilibrium between water supplied and demanded. An important macroeconomic aspect of what can happen to water supply and demand in the long-term is the effect of technological change. For example, from 1950 to 1980, the patterns of water use show a steady increase that, however, was reversed by a decrease from 1980 to 1985. A structural change in the US economy occurred between 1980 and 1985. After 1985, water uses have remained approximately steady [9] while, from 1950 to 1995, the US population increased at a relatively constant rate from 150 million to 250 million, and in 2006 it is approximately 300 million people. The consumptive use of water in 1995 was about 100 billion gallons per day, BGD $(378,541,180,346 \mathrm{lpd})$, approximately $29 \%$ of the total water withdrawals [10]. Population changes in trend, composition, and location are a major reason for changing water demand and supply at the levels of detail that we have adopted. The relatively predictable demographic effects of an aging population can affect the supply of water in a number of ways including the potential for retirees to migrate between water districts. A less predictable, but nonetheless important, unknown is the effect of droughts on water supply and the social and economic dislocations that severe droughts can cause. Another important unknown involves societal and political attitudes regarding the management of ecological assets via minimum stream flow requirements for sustaining aquatic communities, in conditions of sustained water scarcity or shortages. When we look for physical factors affecting water supply and demand, little is known about cold and heat waves. Similarly, few studies provide information on the frost-free seasons, cold and warm days for the northeastern United States and trends in the exceedance of 0 degrees centigrade and 32.2 degrees centigrade thresholds for the United States [2]. Increased precipitation, as number of days in a year exceeding $50.8 \mathrm{~mm}$ and $101.6 \mathrm{~mm}$., have been increasing since 1910 as have interval exceedences and their frequencies ( 1 to 7 - day totals, 1:1 and 1:5 year return periods). Nonetheless, the droughts in the 1930s and 1950s still dominate long-term time series [2] thus adding uncertainty to the current projections.

No analysis of sustainability of water uses can be complete without accounting for water pollution. It results from many diverse sources. For example, point sources include industrial and sewage treatment discharges, underground storage tanks leaks and spills. Non-point sources include agriculture, silviculture, construction, mining, urban run-off, septic fields, and landfills. For some sources of water pollution, their classification as either point or non-point source can be somewhat arbitrary because it is a judgment based on the regulatory agency's administrative rules that limit discharge 
of water to a receiving body, such as a bay or river. Natural erosion can decrease water storage and affect tourism by increasing turbidity and reducing water depth; it increases dredging and irrigation costs, and hinders natural water filtration, but knowledge about these, including pollution and risks generated by dredging, is incomplete [11].

Table 2 summarizes water use projections made by Brown [10,12] and the 1995 data developed by Solley, Pierce, and Perlman [7], (the basis for the projections is a water budget in which withdrawals = consumption + return flows + recharges). These projections use the Census Bureau (1992) and Bureau of Economic Analysis (1992) data for states and counties, and income data from the Bureau of Economic Analysis (1992). The results are aggregated at the WRR level by Brown [10, 12] and others, which we summarize in Table 2.

Key aspects of US water quality are summarized in Tables 3-6. Table 3 describes the aggregate qualitative status of water quality - as the degree of support for specific uses - in 1988 and 1990; it is based on data from states and other jurisdictions reporting to the US EPA, under the Clean Water Act Section 305(b). The reporting jurisdictions assessed approximately 520,000 river miles $(836,859 \mathrm{~km})$ and $1,8000,000$ stream miles $(2,896,819 \mathrm{~km})$, but the percentage of waters assessed by some jurisdictions were much lower than the percentage of water assessed by other jurisdictions; some jurisdictions sampled their waters, but others used models to predict water quality. In 1988, approximately 16 million ac $(6,475,111 \mathrm{ha})$ of lakes, ponds, and streams were assessed with reporting issues similar to those for rivers and streams. Approximately 27,000 square miles (69,930 square $\mathrm{km})$ of estuaries were assessed; the range of the assessed waters varying from 2 to over $90 \%$, depending on the jurisdiction submitting the data. Approximately 4,500 miles $(7,242 \mathrm{~km})$ of the Great Lakes shorelines were assessed but the assessments are characterized by considerable differences in the reporting methods. There were approximately 3,800 miles $(6,116 \mathrm{~km})$ of assessed ocean coastal waters; however, approximately half of the reporting jurisdiction reported monitoring data, while the others were 'evaluative' assessments and the variability of the assessed water ranged from 4 to $100 \%$ assessed. The status and percentage of water uses supported at levels such as 'good' and 'fair' are shown in Table 3, from data that we summarize from the US EPA [13, 14].

Eight years later, in 1996, the quality of American waters, from information reported from states and other jurisdictions under Section 305(b), can be described more fully through a wider spectrum of uses $[15,16]$. For that year, there are 54 reporting jurisdictions that surveyed approximately 700,000 miles $(1,126,541 \mathrm{~km})(19 \%$ of the total miles) of rivers and streams, out of a total of 3,600,000 miles $(5,793,638 \mathrm{~km})$. The quality of lakes, ponds, and reservoirs is reported by 45 jurisdictions that surveyed $16,800,000$ acres $(6,798,867 \mathrm{ha})(40 \%$ of the total $41,700,000$ acres or $16,875,759$ ha); different form of pollution (e.g. mercury, or other, such as eutrophication) affect these bodies of water. Approximately $94 \%$ of the Great lakes' 5,521 shore miles $(8,885 \mathrm{~km})$ have been surveyed (i.e. 5,186 miles or $8,346 \mathrm{~km}$ ); of these, about $97 \%$ are characterized by fish consumption advisories. The quality of estuarine waters surveyed by 23 jurisdictions $(28,819$ miles or $46,380 \mathrm{~km})$ is $72 \%$ of the total 39,839 miles $(64,115 \mathrm{~km})$. Finally, 10 jurisdictions surveyed their ocean coastlines, namely 3,651 miles or $5,876 \mathrm{~km}(6 \%)$, out of 27 jurisdictions: a total of 58,585 miles $(94,283 \mathrm{~km})(94 \%)$ remained to be surveyed. These results for 1998 are depicted in Table 4.

In 1998 there were 842,426 river miles $(1,355,753 \mathrm{~km})(23 \%)$ assessed, out of a total 3,662,255 miles $(5,893,828 \mathrm{~km})$. Approximately 17,390,000 acres $(70,376,637 \mathrm{ha})(42 \%)$ of the lakes, reservoirs, and ponds were assessed, out of a total of approximately 41,378,000 acres (16,745,447 ha), from data provided by 45 jurisdictions that relied on monitoring, and other evaluations. For estuaries, for which 22 jurisdictions out of 27 have provided water quality information the situation was as follows: 28,687 square miles $(74,299$ square $\mathrm{km})(32 \%)$ of the total 90,465 square miles 


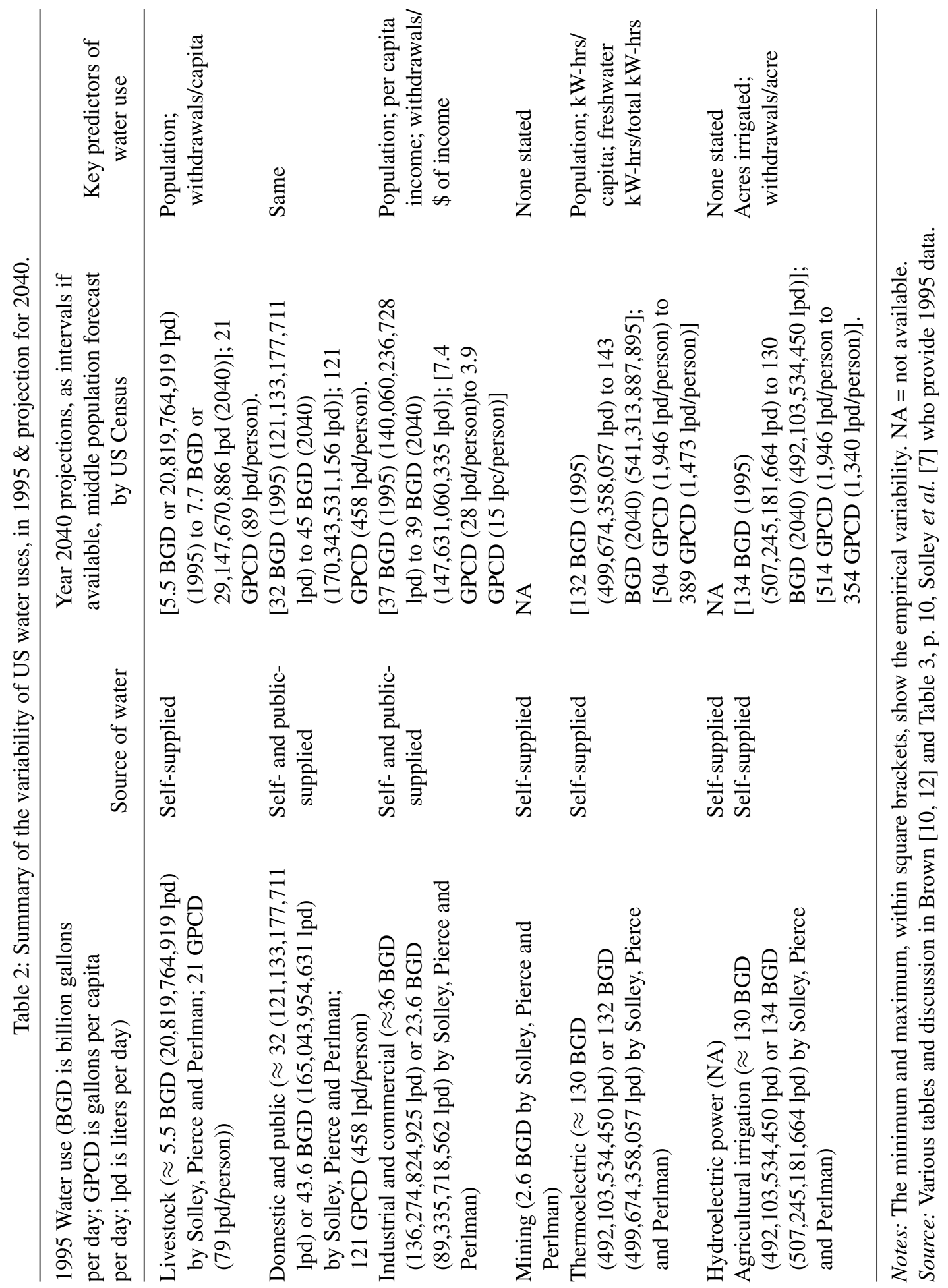


Table 3: Status and percentage of uses supported in 1988, adapted from US EPA [14] (EPA 440-490-003).

\begin{tabular}{llc}
\hline & \multicolumn{2}{c}{ All uses } \\
\cline { 2 - 3 } & \multicolumn{1}{c}{ Good $(\%)$} & Fair $(\%)$ \\
\hline Rivers and stream & $70(361,332 \mathrm{miles} ; 581,507 \mathrm{~km})$ & $20(104,632 \mathrm{miles} ; 168,389 \mathrm{~km})$ \\
Lakes, ponds and reservoirs & $74(12,021,044 \mathrm{ac} ; 4,864,850 \mathrm{ha})$ & $17(2,701,577 \mathrm{ac} ; 1,093,313 \mathrm{ha})$ \\
Estuaries & $72\left(19,110 \mathrm{mi}^{2} ; 49,495 \mathrm{~km} \mathrm{sq}\right)$ & $23\left(6,078 \mathrm{mi}^{2} ; 15,742 \mathrm{~km} \mathrm{sq}\right)$ \\
Great Lakes shorelines & $8\left(372 \mathrm{miles}^{2} 599 \mathrm{~km}\right)$ & $18\left(819 \mathrm{miles}^{2} 1318 \mathrm{~km}\right)$ \\
Ocean coastal waters & $89(3,324 \mathrm{miles} ; 5349 \mathrm{~km})$ & $8(307$ miles; $494 \mathrm{~km})$ \\
\hline
\end{tabular}

Notes: Good is fully supporting and fair is partially supporting; all uses means designated uses: fisheries, contact recreation, and drinking water. Forty-eight jurisdictions reported data on water quality, but the information on rivers and streams from 10 jurisdictions were unusable for the purpose of the CWA $\$ 305(b)$ reporting. For estuaries, data were reported by 28 jurisdictions, with data from 7 jurisdictions being unusable. Of the 8 Great Lakes States, 6 provided data. Twelve jurisdictions reported the status of their coastal waters.

Source: US EPA [14], Figures 1-1, 2-1, 3-1 and 4-8.

Table 4: Status and percentage of uses supported in 1996, developed from US EPA [15] (EPA 841S-97-001).

\begin{tabular}{lcccc}
\hline & $\begin{array}{c}\text { Full support } \\
\text { all uses } \\
\text { (Good) }(\%)\end{array}$ & $\begin{array}{c}\text { One or more uses } \\
\text { threatened } \\
(\text { Good })(\%)\end{array}$ & $\begin{array}{c}\text { One or more uses } \\
\text { impaired } \\
\text { (Impaired) }(\%)\end{array}$ & $\begin{array}{c}\text { Not } \\
\text { attainable } \\
(\%)\end{array}$ \\
\hline $\begin{array}{l}\text { Rivers and streams } \\
\text { Lakes, ponds and } \\
\text { reservoirs }\end{array}$ & 51 (lakes only) & 10 (lakes only) & 39 (lakes only) & $<1$ (lakes \\
The Great Lakes & 2 & 1 & 97 & $<1$ \\
Estuaries & 58 & 4 & 38 & $<1$ \\
Ocean shoreline & 79 & 9 & 13 & 0 \\
waters & & & & 36 \\
\hline
\end{tabular}

Notes: Good, Impaired and Not attainable are short descriptions used by the US EPA to characterize the status in the columns' headings. Wetlands data are not reported in this table for brevity. Source: Developed from Figures 3, 6, 9, 12 and 15, US EPA [15].

$(234,303$ square $\mathrm{km})$ were assessed. Finally, approximately 3,130 miles $(5,037 \mathrm{~km})(5 \%)$ of ocean shorelines were assessed, out of 66,645 total miles (107,255 km), including Alaska's. As discussed for 1996, these data are developed from heterogeneous reporting methods: for example thirteen States rated swimming, six fish consumption, and eight shellfish consumption. The results for 1998 are shown in Table 5.

An indication of the progress in measuring the status of US waters in the percentages of the body of waters assessed in the last decade is depicted in Table 6, which is developed from the data US EPA [17] data. 
Table 5: Status and percentage of uses supported in 1998, developed from US EPA [17] (EPA 841R-00-001).

\begin{tabular}{lccccc}
\hline Water body & $\begin{array}{c}\text { Fully supporting } \\
\text { all uses } \\
\text { (Good) }(\%)\end{array}$ & $\begin{array}{c}\text { One or more uses } \\
\text { threatened } \\
(\text { Good })(\%)\end{array}$ & $\begin{array}{c}\text { One or more } \\
\text { uses impaired } \\
\text { (Impaired) }(\%)\end{array}$ & $\begin{array}{c}\text { Not } \\
\text { supporting } \\
(\text { Poor })(\%)\end{array}$ & $\begin{array}{c}\text { Not } \\
\text { attainable } \\
(\%)\end{array}$ \\
\hline $\begin{array}{l}\text { Rivers and } \\
\text { streams }\end{array}$ & 55 & 10 & 35 & 5 & $<0.02$ \\
$\begin{array}{c}\text { Lakes, } \\
\text { reservoirs, } \\
\text { and ponds }\end{array}$ & 46 & 9 & 45 & $5^{*}(0,67)^{\mathrm{a}}$ & $<0.01$ \\
$\begin{array}{c}\text { The Great } \\
\text { Lakes }\end{array}$ & 2 & 2 & 96 & $12^{*}$ & 0 \\
$\begin{array}{c}\text { Estuaries } \\
\text { Ocean } \\
\text { shoreline }\end{array}$ & 47 & $>9$ & 44 & $3^{\#}$ & 0 \\
\hline
\end{tabular}

Notes: *Geometric average of the percentages for six uses (aquatic life, fish consumption, swimming, secondary contact, drinking water supply, and agriculture).

${ }^{a}$ The numbers in parenthesis are the minimum and the maximum of the six values used in calculating the geometric average.

${ }^{\#}$ Geometric average of four reported uses (aquatic life support, fish consumption, swimming and secondary contact).

Source: EPA 841-R-00-001 [17]: Figures 3-2, p. 58, 4-2, p. 84, 5-1, p. 104, Tables 3-3, p. 60, 8-3, p. 203. Figures 3-3, p. 60, 4-3, p. 85, 5-7, p. 112. Figure 5-2, p. 105, and Figure 5-11, p. 117.

This data shows significant differences between the years, although some of the differences are due to the inclusion of Alaska and to the changes in the basis for the calculation of percentages. These overall results, discussed in more detail in the next section, do not permit inference to the nation's water because of their heterogeneity in reporting, types of sampling, evaluation criteria, and possibly different and incomplete modeling used for predictions in assessing the quality of water for specific uses. We concur with Vorosmaty et al. [18] that the vulnerability of water resources to climate change and the effect of population growth on demand require the joint analysis of water quality demanded, supplied, and quality. We provide some of the needed information in the next sections, which describe the water situation for the United States using WRR (for water supply and demand) and states (for water quality).

\section{WATER SUPPLY AND DEMAND: BASELINE AND A VIEW ON THE FUTURE}

US WRR (from WRR 1 to WRR 20) are used by Guldin [19] to develop water budgets from 1985 to 2040 and by Brown's [10] projections. Guldin's analyses have data gaps (the period 1985 to 2000) that can affect understanding potential changes in water supply and demand from 2000 to 2050. Solley, Pierce, and Perlman [7] for the year 1995 provide additional information needed to 'fill' gaps in the data and projections developed by Guldin[19]. (The basic water budget is the balance of the following factors, over the $k$ years time horizon ( $k=55$ years for Guldin [19]); average annual precipitation, renewable water supply, groundwater overdrafts, imports or exports, net reservoir evapo-transpiration, 


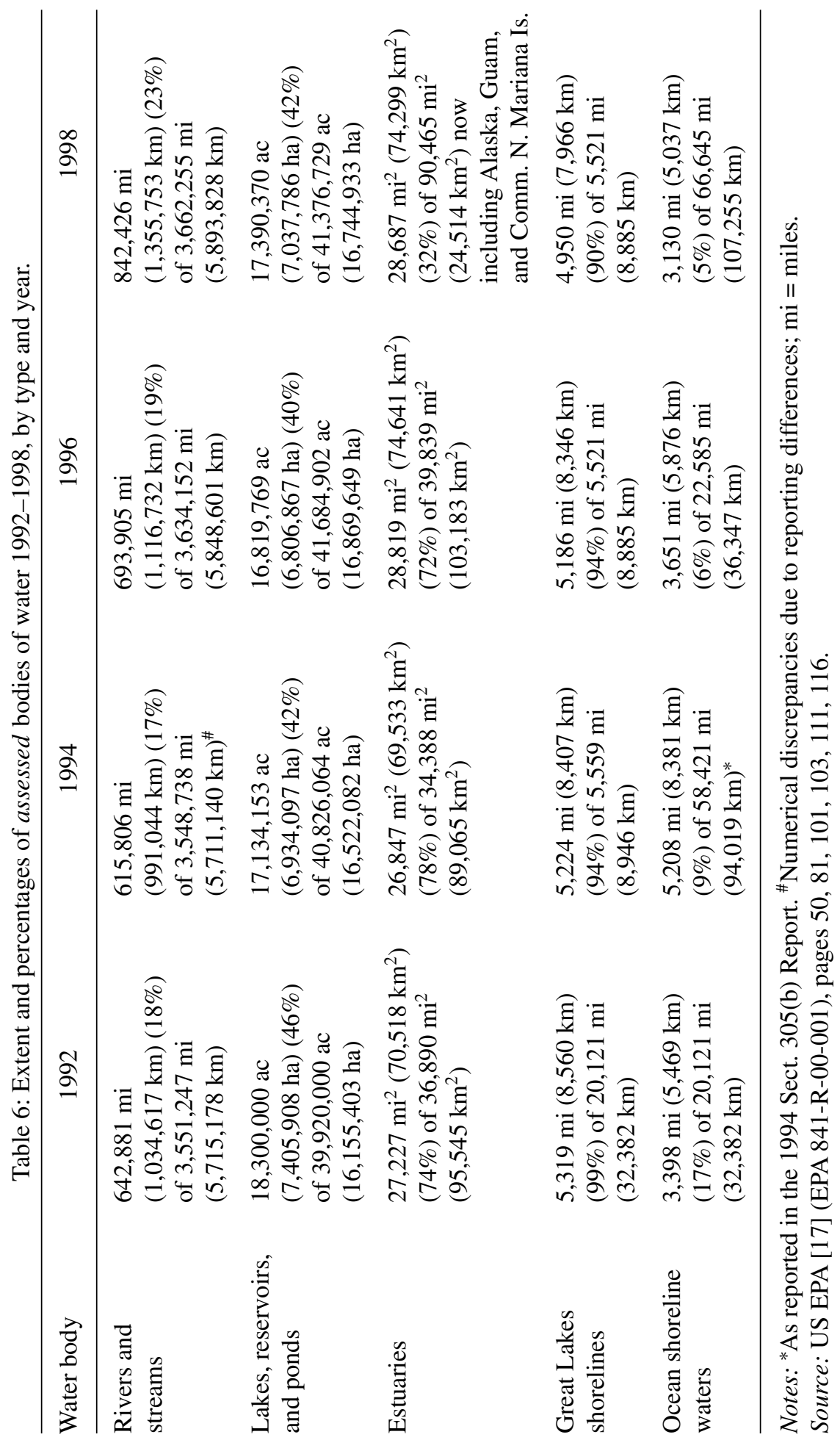


Table 7: Determinants of water use and trends up to 2040.

\begin{tabular}{|c|c|c|}
\hline Water demand by user & Example of determinants of demand & Trends [12] \\
\hline Livestock & $\begin{array}{l}\text { Consumer taste, income, } \\
\text { potential diseases. }\end{array}$ & $\begin{array}{l}\text { 5.5 BGD }(20,819,764,919 \\
\text { lpd) in } 1995 \text { to } 7.7 \text { BGD } \\
(29,147,670,887 \text { lpd }) \text { in } 2040 \\
\text { with possibly higher increases }\end{array}$ \\
\hline Domestic and public & $\begin{array}{l}\text { Housing stock, technological } \\
\text { innovations and modernization, } \\
\text { conservation. Water withdrawal } \\
\text { rates to follow population } \\
\text { growth rate }\end{array}$ & $\begin{array}{l}\text { Historical rates of change: } 1.5 \% \\
\text { in the } 60 \mathrm{~s}, 0.9 \% \text { in the } 70 \mathrm{~s} \text {, } \\
0.8 \% \text { in the } 80 \mathrm{~s}, 0.3 \% \text { in the } \\
\text { period } 1990-95 . \text { Expected to } \\
\text { increase from } 32 \mathrm{BGD} \\
\text { ( } 121,133,177,711 \mathrm{lpd}) \text { to } 45 \\
\text { BGD }(170,343,531,156 \mathrm{lpd}) \text { in } \\
2040 \text { ( } 42 \% \text { increase) }\end{array}$ \\
\hline $\begin{array}{l}\text { Industrial and } \\
\text { commercial (I\&C) }\end{array}$ & $\begin{array}{l}\text { Efficiency, consumer confidence, } \\
\text { employment rates, changes in taxes } \\
\text { Withdrawals predicted on the basis } \\
\text { of GPD/ } \$ 1000 \text { personal income, } \\
\text { income/caput, population. }\end{array}$ & $\begin{array}{l}2.5 \% \text { in the } 60 \mathrm{~s}, 2.3 \% \text { in the } 70 \mathrm{~s} \text {, } \\
6.1 \% \text { in the } 80 \mathrm{~s}, 1 \% 1990-95 \\
\text { and about } 1.5 \% \text { to } 2040\end{array}$ \\
\hline $\begin{array}{l}\text { Thermoelectricity } \\
\text { generation }\end{array}$ & $\begin{array}{l}\text { As for the I\&C sectors, } \\
\text { federal and state energy policy. } \\
\text { Predictions based on } \\
\text { total kW-hrs/person. }\end{array}$ & $\begin{array}{l}\text { Historical rates of total energy } \\
\text { (kW-hrs) uses: 6\% in the 60s, } \\
3 \% \text { in the } 70 \mathrm{~s}, 1.1 \% \text { in the } 80 \mathrm{~s} \text {, } \\
0.4 \% \text { 1990-95, } 0.6-0.14 \% \\
1990-95 . \text { Freshwater use per } \\
\mathrm{kW}-\mathrm{hr} \text { to decrease from } 1.3 \% \\
\text { in } 1995 \text { to } 0.6 \% \text { in } 2040\end{array}$ \\
\hline Agriculture & $\begin{array}{l}\text { Urban sprawl, energy } \\
\text { costs, technological } \\
\text { changes, taste, income, } \\
\text { transportation, climate change, } \\
\text { federal and state policy. } \\
\text { Predictions based on } \\
\text { withdrawals/acre. }\end{array}$ & $\begin{array}{l}\text { Western US: annual rates } \\
\text { decreased from } 1 \% \text { from } 1980 \\
\text { to } 1985,0.1 \% \text { from } 1985 \text { to } \\
\text { 1995. Predicted to decrease } \\
\text { 0.08 to } 0.04 \text { per year to } 2040 \\
\text { Eastern US: predicted have no } \\
\text { growth to } 2040\end{array}$ \\
\hline
\end{tabular}

$\mathrm{BGD}=$ billion gallons per day; $\mathrm{kW}-\mathrm{hr}=$ kilowatt-hour.

non-agricultural off-stream consumptive uses, average stream outflows and instream flow requirements. The critical assumptions based on constant prices, constant institutional framework, are that the average is the optimal metric and that the instream flow requirements are optimal with respect to fish and wildlife habitats. Variability about the average precipitation is taken to be $\pm 20 \%$. Some of the components of the water budget include additional factors such as self-supply.) The principal classes of water users developed by the USGS [10] are: livestock, domestic and public, industrial and commercial, thermoelectric, and irrigation. Table 7 contains a summary of the predictions of water demands (often stated as withdrawals) by these users and examples of the determinants of the demand for water. 
From 1960 to 1985 the total water withdrawals of the United States increased by approximately $60 \%$, consumptive use increased by $50 \%$; thermoelectric consumptive use increased by more than $1,800 \%$, irrigation by $40 \%$, groundwater withdrawals by $80 \%$ and surface water withdrawals by $50 \%$. By contrast, the more recent data - based on 1995 numbers - are as follows:

1. Livestock (cattle, hog, sheep, and poultry) withdrawals. The predictions are not based on the number of animals because this data is not available; the proxy used is meat consumption. On that basis, the daily water withdrawals per capita were slowly declining from about 10 GPD (38 lpd/person) in 1980 to about 8.5 GPD (32 lpd/person) in 1995 [12]. However, accounting for other animal stock raises the GPD withdrawals from about 2 GDP ( $8 \mathrm{lpd} /$ person) in 1980, to about $22 \mathrm{GPD}$ (83 lpd/person) in 1995, with a steady use at about $18 \mathrm{GPD}$ (68 lpd/person) from 1985 to 1995. Solley, Pierce, and Perlman [7] state that 5.50 BGD (21 lpd/person) were used by this sector in 1995.

2. Domestic and public use withdrawals. Overall, from 1960 to 1995 , water withdrawals, either in gallons per capita per day or in gallons per household per day, have been increasing but are essentially constant from 1990 to 1995 . The per-capita withdrawals increased from approximately $86 \mathrm{GPD}$ (326 lpd/person) in 1960 to $122 \mathrm{GPD}$ (462 lpd/person) in 1990, but then decreased to 120 GPD (454 lpd/person) in 1995 [12], Solley, Pierce, and Perlman [7] calculate that 43.60 BGD $(165,043,954,631 \mathrm{lpd})$ were used in 1995 . Per-household data are valuable because they reflect the decline in the number of individuals per household due to changing social and economic factors.

3. Industrial and commercial use. Brown $[10,12]$ has used gallons/day/ $\$ 1000$ income to capture the essence of the past trend in water withdrawals by the industrial and commercial sectors. The trend, from a high of approximately 24 gallons/day/ $\$ 1,000$ in 1960 (90 lpd/ $\$ 1,000)$, has steadily declined to about 7.5 gallons/day $/ \$ 1000(28 \mathrm{lpd} / \$ 1,000)$ in 1995 . The reasons for the decrease include increased process efficiency and recycling. The 1995 water quantities developed by Solley, Pierce, and Perlman [7] are 23.60 BGD (89,335,718,561 lpd) of fresh water, with an additional 1.66 BGD $(6,056,658,886 \mathrm{lpd})$ of saline water used by the industrial sector only.

4. Thermoelectric use. The pattern of water use from 1960 to 1995, measured in gallons/day, has been declining. The shape of the function is almost the same as that of the industrial and commercial use (roughly shaped as a negative exponential function), from a high of 60 gallons/ KW-hr (227 liter/KWh-hr) to a low of about 23 gallons/kW-hr (87 liter/KW-hr). The production of electricity from 1960 to 1995 has increased from about 450 to $215010^{9} \mathrm{~kW}-\mathrm{hr}$. The decrease in water usage per unit of energy produced is primarily due to re-use. Thermoelectric power generation water withdrawals for 1995 calculated by Solley, Pierce, and Perlman [7] are 132 BGD $(499,674,358,057 \mathrm{lpd})$ of freshwater and 57.9 BGD (219,173,433,420 lpd) of saline water.

5. Irrigation use. The demand for water has shown a positive trend from 1960 to 1980 , declining to approximately in 1995. A major reason for the decline in water withdrawals is the shift, over that period of time, from irrigated agriculture in the West (WRRs 10 through to 18) to the East (WRRs 1 through 9). The East requires less water per acre for irrigation than the West due to greater levels of rainfall. Other reasons suggest that there have been efficiency gains, which have taken into account plant evapo-transpiration, and the price of pumped water has increased. Solley, Pierce and Perlman [7] calculate irrigation withdrawals to be 134 BGD $(507,245,181,663$ lpd).

6. Hydroelectric power. The production of electric power has increased from approximately $150 \times$ $10^{9} \mathrm{~kW}$-hr in 1960 to $310 \times 10^{9} \mathrm{~kW}$-hr in 1975 , becoming fairly stable from 1975 to 1995 , at about $300 \times 10^{9} \mathrm{~kW}$-hr. Water withdrawals have declined from a high of approximately 5,000 gallons/KW-hr (18,900 1/KW-hr) in 1960 to 3,800 gallons/kW-hr (14,400 1/KW-hr) in 1995. 
However, water withdrawals have increased from approximately $2 \times 10^{12}$ GPD $(7,570,823,606$, $923 \mathrm{lpd})$ in 1960 to $3 \times 10^{12} \mathrm{GPD}(1,1356,235,410,384 \mathrm{lpd})$ in 1975 , remaining constant thereafter.

The 1995 magnitude of the withdrawals from surface and ground water sources is developed from Solley, Pierce, and Pearlman ([7]; definitions of each water region can be found in this reference) and is summarized in Table 8.

Domestic and public water, livestock and commercial and industrial water demands correlate as depicted in Fig. 1. This Figure suggests that there are a few outliers, but most of the data appears to be within the $95 \%$ confidence ellipse.

To gain additional insights, we depict clusters of WRRs within the WRR data. The dendrogram (estimations by Ward's method) of the domestic and public water demands (from Table 8) depicts their clustering (Fig. 2): the clusters suggest some of the potential relationships between WRRs and water demands by the public and domestic, livestock, and commercial and industrial sectors of the US economy. The graphs in Fig. 2 depict the dendogram and the scree diagram of the clusters.

The clusters are indicated by the dots ', , 'x' and 't' codes in Fig. 2. The scree plot also suggests that there are three major clusters of WRRs: each change in the slope of the line slope indicates a clustering of WRRs. The cluster (+) consists of the N. Atl., S. Atl, G. Lakes, and Ohio WRRs. The cluster (x) consists of the L. Miss, Souris R, Pac NW, and CA WRRs. The third cluster (.) accounts for the remaining WRRs. The surface and ground water withdrawals at the WRR level by economic sector, in 1995, are summarized in Table 9.

The predictions of changes in water withdrawals from 1995 to 2040 , by WRR, developed by Brown [10, 12] and Guldin [19], using the 1995 US Census Bureau Population Series Projections, are summarized in Table 10.

The clusters are indicated by the dots '.', 'x' and '+' codes in Fig. 3. As for the previous analysis, there are three clusters. These are North Atlantic, Great Lakes and California (x), South Atlantic (+), and the rest of the WRRs forming the third cluster (.).

Table 11 depicts a plausible distribution of the per capita domestic and public water withdrawals up to 2040 [12].

\subsection{Surface water surpluses and deficits}

The sensitivity of the water demands can be assessed by using recent population projections made by the US Census Bureau [5] and adopting average water consumption as shown in Table 12.

These results are based on average daily demand held constant throughout the three periods of time (2000, 2040, and 2050), multiplied by the predicted population numbers provided by the US Census Bureau, and then converted to BGD. For example: 122 gallons per capita per day demand by domestic and private sources multiplied by $274,853,000$ people in the United States in 2000 equals $3.3 \times 10^{10}$ gallons per day or 33 BGD ( $\left.125 \mathrm{bld}\right)$. The population numbers are those provided in an earlier Table of this Report. The second assumption is that the unit water demands apply to the population as a whole. The daily water per capita demand is that given in Brown [12] (Table A1.7, p. 42). If we use the average sectoral consumption (that is 122, 106, 389 and 354 GPCD; $462,405,1,473 \mathrm{lpd} /$ pers on) for 2040, and use the difference in the highest series population number in $2040(475,949,000)$ and Guldin's 2040 population estimate for that year at 333,300,000 we obtain 142,550,000 people as the potential positive population gap in that year. The corresponding sectoral consumption gaps for 2040 become: domestic and public $=17.4$ BGD (65.87 bld); industrial and commercial = 15.1 BGD (57.6 bld); thermoelectric $=55.5$ BGD (210.09 bld $)$; and agricultural $=50.5$ BGD $(191.16$ bld $)$. Clearly, population may increase at either a slower rate or at 


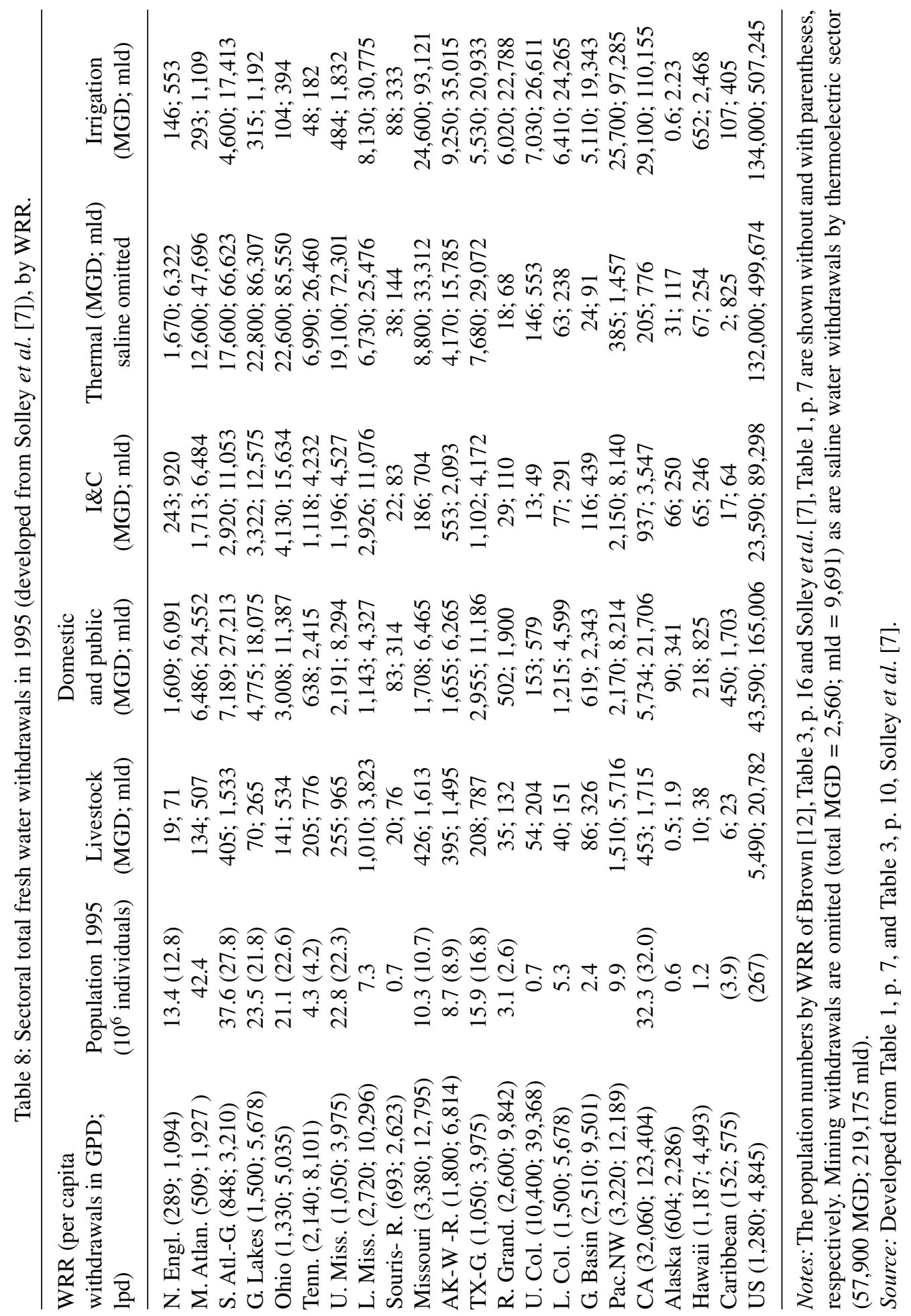




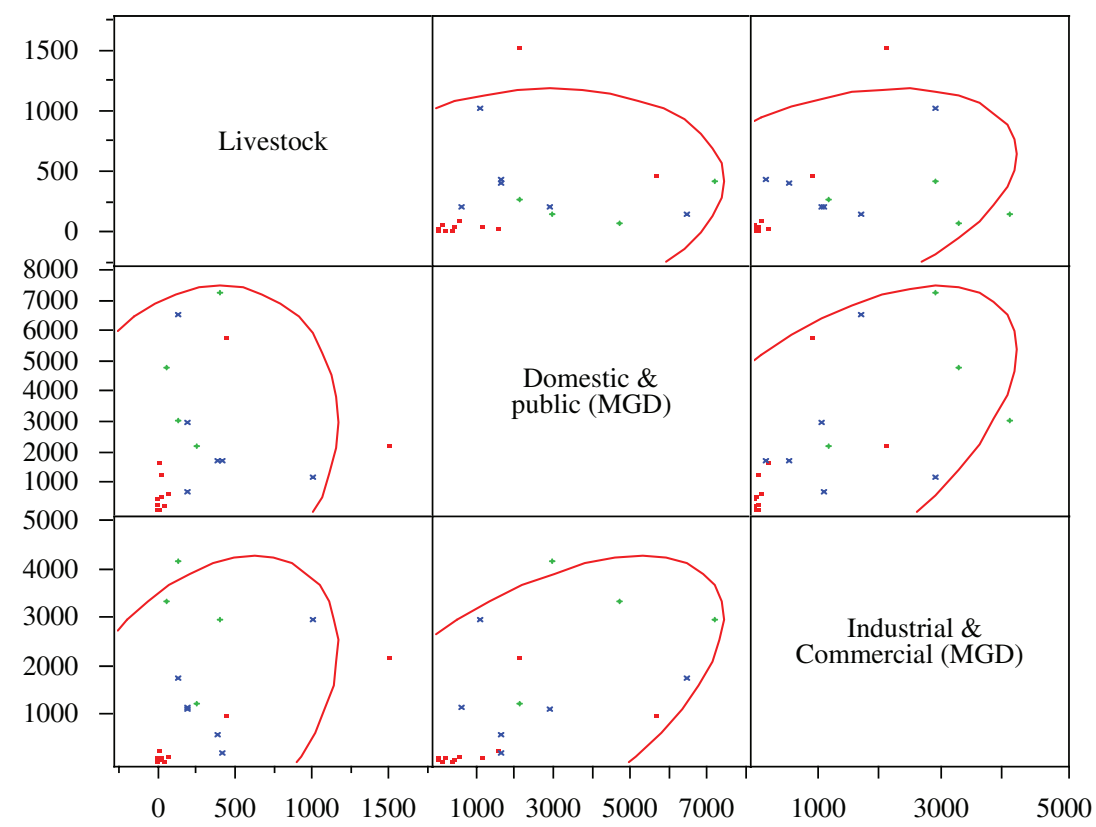

Figure 1: 95\% Confidence ellipse for domestic and public water, livestock, commercial, and industrial water demands in MGD (WRRs data for 1995, Table 8).

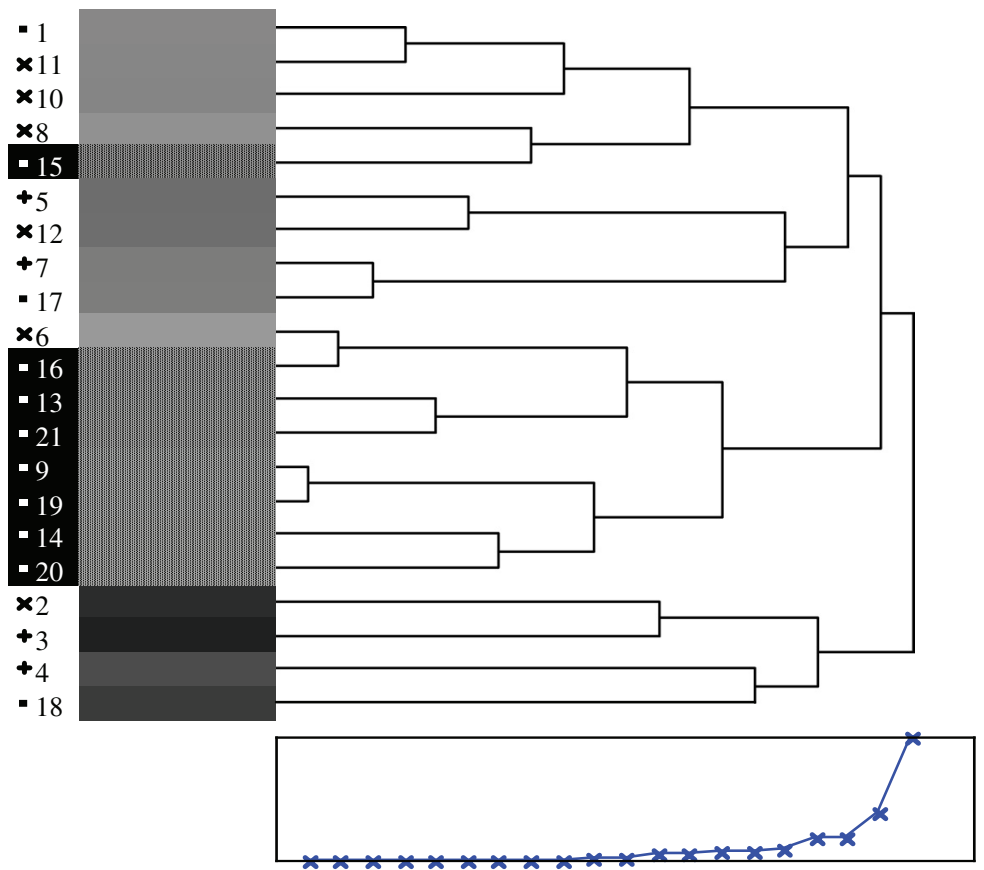

Figure 2: Clusters of WRRs (from Table 8 data.) 


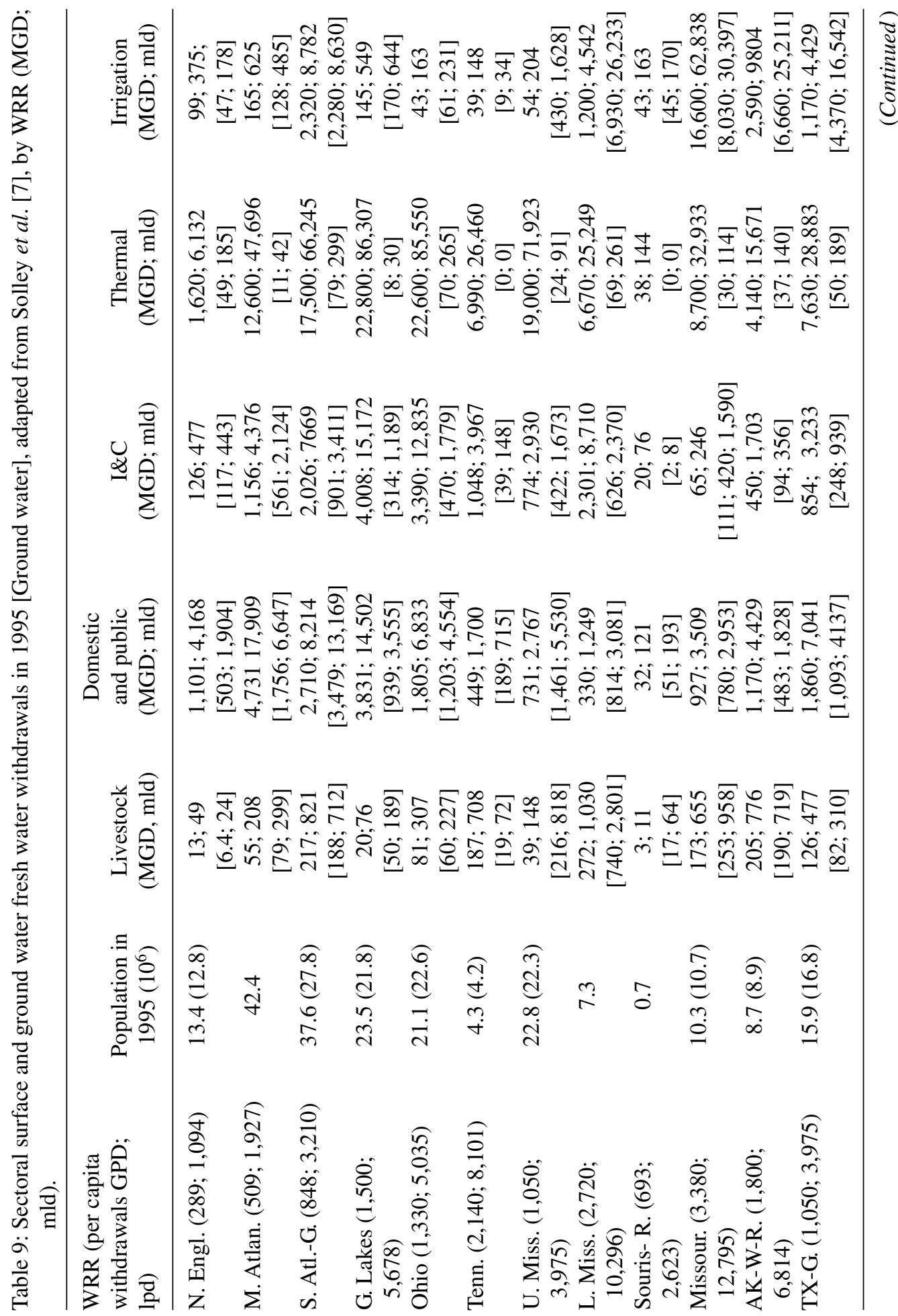




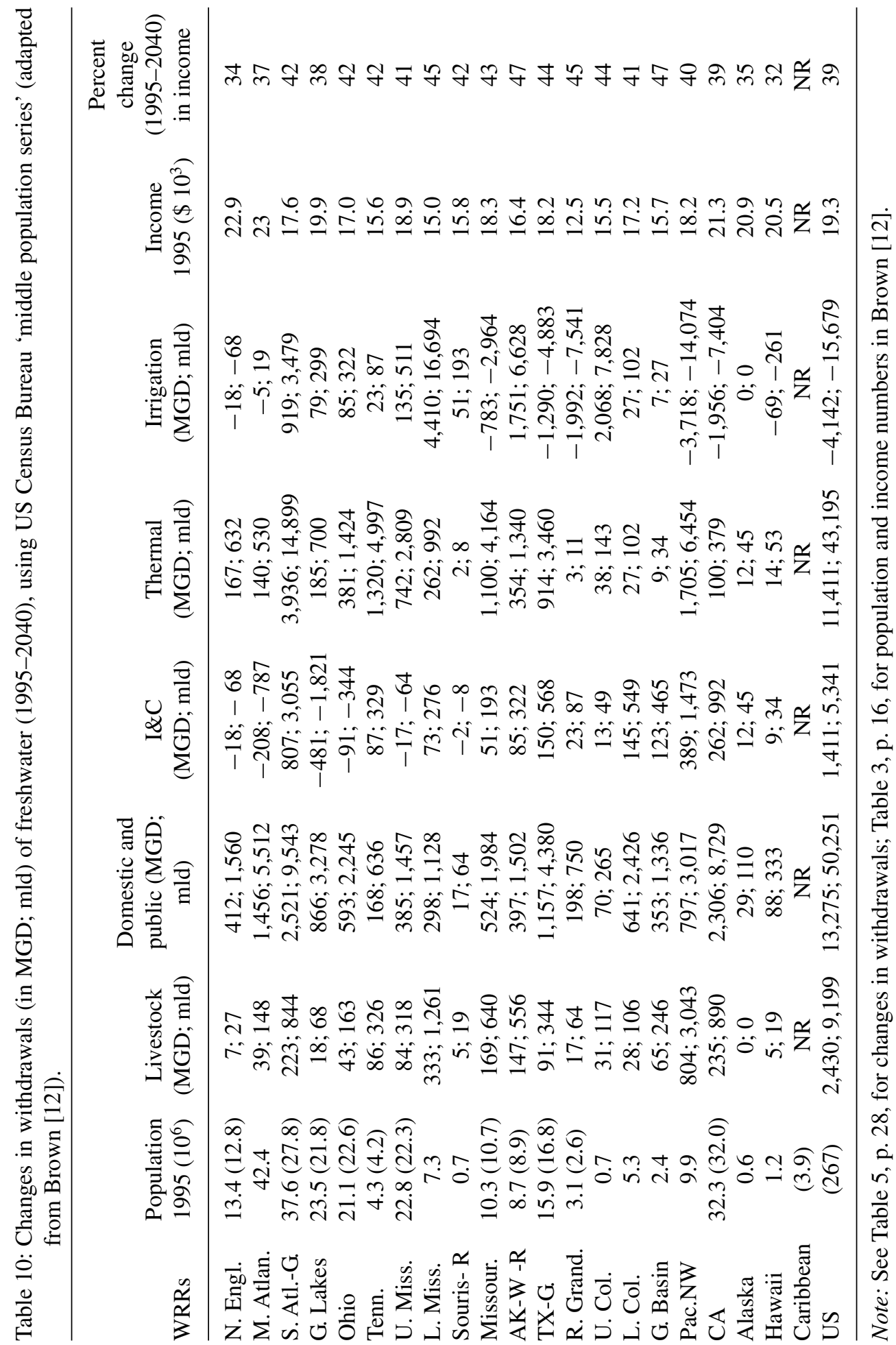




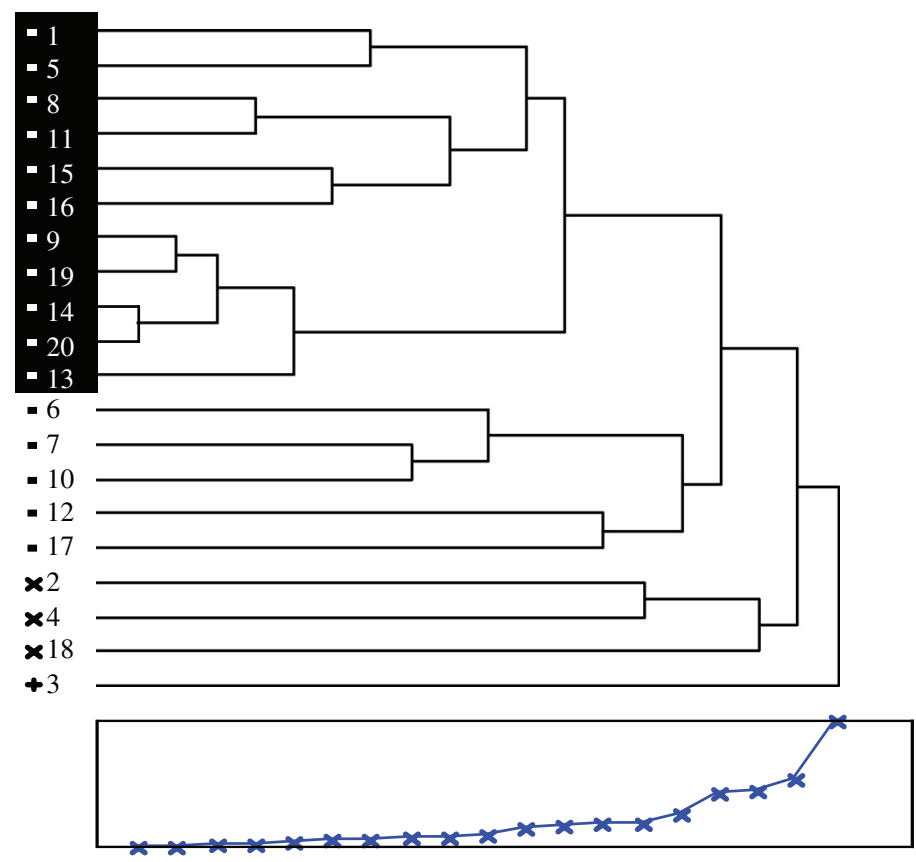

Figure 3: Cluster analysis (data from Table 10).

Table 11: Per capita domestic and public withdrawals, 1995 and projections for 2040.

\begin{tabular}{lcccc}
\hline Measures & Base year 1995 & 2040 Low & 2040 Best guess & 2040 High \\
\hline $\begin{array}{l}\text { Gallons per person/ } \\
\text { day; lpd/person } \\
\begin{array}{c}\text { Domestic and public } \\
\text { (BGD; bld) }\end{array}\end{array}$ & $121 ; 458$ & $115 ; 453$ & $122 ; 462$ & $134 ; 507$ \\
Total US (BGD; bld) & $32 ; 121$ & $42 ; 159$ & $45 ; 170$ & $49 ; 185$ \\
\hline
\end{tabular}

Source: Table 10, p. 32, Brown [12].

a faster rate, depending on immigration policies and other labor-related considerations. However, if the gap leads to local or regional shortages, infrastructure must be put in place to deal with it.

\section{WATER QUALITY}

We have selected the data sets that the states and other major jurisdictions provided to the US EPA, under section 305(b) of the Clean Water Act. This data set is homogeneous with respect to the protocols that the states and other jurisdictions have adopted and include the input from a number of stakeholders, such as Indian Tribes. Nevertheless, there are differences in the summaries developed by each jurisdiction and provided to the US EPA, due to changes in the monitoring networks, the number of stations recording from time to time, differences in the methods for assessment, and so on. 


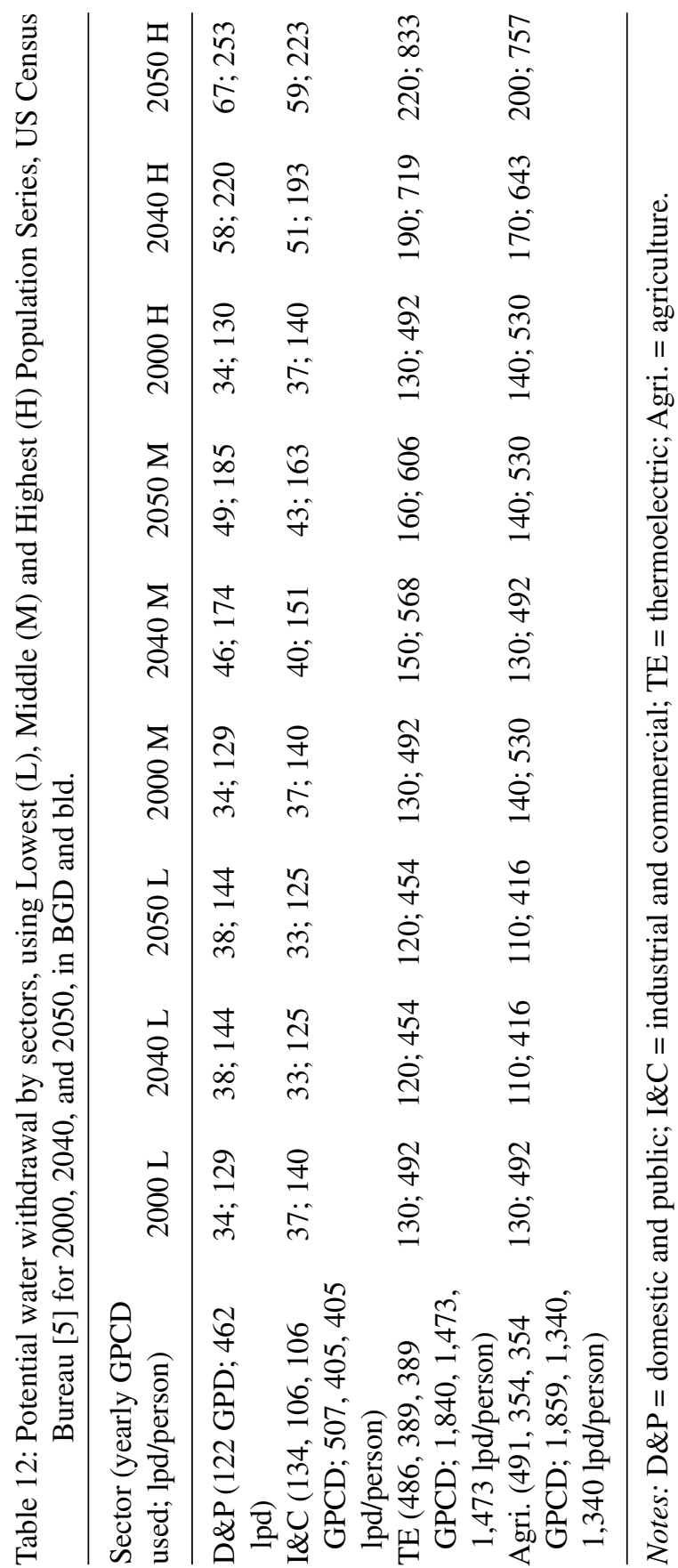




\subsection{Surface Water}

Earlier results about the quality of US water are available for 1988 (US EPA [14], EPA 440-4-90003). We limit the discussion to status: good, meaning fully supporting and fair, meaning partially supporting (from the sets of fully supporting, threatened, partially supporting, not supporting, and not attainable as used by the EPA), for brevity and because two uses (fully supporting and partially supporting) are often the largest, as percentages. The US EPA's 1988 assessment is based on about 520,000 assessed miles $(836,859 \mathrm{~km})$ of rivers (48 jurisdictions), 16,000,000 assessed lake-acres $\left(64,750 \mathrm{~km}^{2}\right)\left(40\right.$ jurisdictions); and 26,700 miles $2\left(69,153 \mathrm{~km}^{2}\right)$ of assessed estuaries (23 jurisdictions). In 1988, the major causes of river pollution were (rank ordered from highest percent of river-miles impacted): silt, nutrients, pathogens such as bacteria, organic matter, metals, pesticides, suspended solids, salinity, flow alterations, habitat modification, $\mathrm{pH}$, and thermal discharges. Table 13 depicts the national aggregate percentages of impaired waters aggregated over major, moderate, and minor impacts (US EPA [14], EPA 440-4-90-003).

In 1990 approximately $42 \%$ of the assessed water of the United Sates were classified as good (fully supporting); in 1996 the percentage increased to 55\% and, in 1998, the percentage was 70\%. In some instances not all uses are given a percentage number in the original sources and, in 1988, data for the oceans shore miles were unavailable. Also, some percentage numbers for a year may have approximately an order or magnitude range (e.g. in 1988, 70\% of the rivers and streams were classified as good, while only $8 \%$ of the shoreline-miles of the Great Lakes were good). Because of the variability, non-reported numbers, and other technical considerations relating to taking averages, these averages should be understood as being qualitative and aggregate descriptions only.

Table 13: Summary of percent of US impaired waters 1988 by cause of pollution (\%).

\begin{tabular}{lccc}
\hline & \multicolumn{3}{c}{ Waters } \\
\cline { 2 - 4 } & Rivers & Lakes & Estuaries \\
\hline Silt & 42 & 25 & 7 \\
Nutrients & 27 & 49 & 50 \\
Bacteria & 19 & 9 & 48 \\
Organic enrichment & 15 & 25 & 29 \\
Metals & 11 & 7 & 10 \\
Pesticides & 10 & 5 & 1 \\
Suspended solids & 6 & 8 & NR \\
Salt/oil and grease & 6 & 14 & 23 \\
Flow & 6 & 3 & NR \\
Habitat modification & 6 & 11 & NR \\
pH & 5 & 5 & $<1$ \\
Thermal/flow alteration & 4 & $3^{\#}$ & $\#$ \\
\hline
\end{tabular}

Notes: ${ }^{\#}$ There is no thermal effect reported for lakes.

Percentages are calculated as the sum of the quantities (in miles or acres) of pollution-specific impaired miles or acres divided by the total impaired miles or acres, for all jurisdictions. Lakes are affected by priority organics $(8 \%)$. Estuaries are affected by priority organics $(4 \%)$, unknown toxicants $(5 \%)$ and other inorganics $(<1 \%)$. Percentages may not add up to $100 \%$.

Source: Developed from EPA 440-4-90-003 [14], Tables A-1, 2-2, and 4-2. 
According to the National Water Quality Inventory (1998), the majority of the water bodies in the United States are adversely affected by 'moderate to high levels of agricultural run-off'. Furthermore, about $1 / 3$ of the US waters were characterized by fish advisories leading to no fish consumption; and about $1 / 5$ of the country has high levels of wetland loss. The principal causes of water pollution are agriculture, hydrological changes, urban run-off, construction, resources extraction, and grazing. For 1998, the US EPA has ranked (1 being the highest) the five principal causes of water pollution (US EPA [15], Table 2, p. 9 and Table 4, p. 13; Figs 4, 7, and 13) and EPA [20] Figs 4, 7, 10, 13, and 16; EPA [17] Fig. 5-8, p. 113), as summarized in Table 14.

The situation, as reported towards the end of 1997 , is that ' $16 \%$ of the watersheds had slight water quality problems, $36 \%$ had moderate water quality problems, $21 \%$ had more serious problems, and sufficient data was lacking to characterize the remaining 27\%' (US EPA [16], p. 3). Specifically, the 1996 and 1998 results (US EPA [16] Fig. 1, p. 7 and US EPA [20] Fig. 1, p. 5) are shown in Table 15.

The status of the nation's waters, by water body and by selected water uses in 1996, is described in Table 16 (developed from data in US EPA [17, 20]).

Table 17 was developed from water quality data from the US EPA [20] to summarize the percent of water uses supported and the degree of support, for 1998.

In 1998 (US EPA [20], EPA 841-S-00-001), from the states' reporting of their rivers' water quality the results are that for the $23 \%$ of the rivers and stream assessed, $55 \%$ of those waters are rated good, $10 \%$ is rated good but threatened, and 35\% is impaired. Of the $42 \%$ of the lakes, reservoirs and ponds assessed, $46 \%$ are fully supporting all uses, $9 \%$ are fully supporting but threatened, and $45 \%$ are impaired. Approximately $32 \%$ of the US estuaries have been assessed, and $47 \%$ are fully supporting, 9\% are fully supporting but are threatened and $44 \%$ are impaired. The situation for the shores of the Great Lakes, $90 \%$ assessed, only $4 \%$ are fully supportive of all uses, and $96 \%$ is impaired.

The 1996 and 1998 water quality of estuaries of the nation as a whole appears to be relatively good, as depicted in Table 18.

The Great Lakes region of the United States was approximately fully surveyed ( $96 \%$ of about 5,500 miles). However, the geometric average of the fully supporting (good) water use (for six uses) is $35 \%$ (range 2-96\%), the partially supporting (fair) is 6\% (range $<1-34 \%$ ) and the not supporting (poor) status averages 22\% (range 0-64\%). (Data from US EPA [15], EPA 841-R-97-008, p. 312, Fig. 12-4, p. 316.) However, within these numbers, there are significant impairment: aquatic life support and fish consumption are poor (not supporting) in about $63 \%$ of the miles surveyed.

The latest nationwide data on water quality that are consistent with the data shown previously are those available for 2002 [21]. Consistent with the reporting used by the EPA in 2002, we use three descriptors: Good, Impaired, and Threatened. We summarize the results as distributions $(n=47$ jurisdictions, mainly the states that have reported to the US EPA including Alaska under the Clean water Act, section 305(b), excluding territories, other jurisdictions, and North Carolina and Washington; we include the arithmetic mean and the standard deviation, SD) in Table 19.

The leading sources of water pollution affecting these assessments include atmospheric depositions, discontinued discharges from pipes, contaminated sediments, land disposal of waste, unspecified non-point sources, various point sources, urban runoff, and storm sewers. The major pollutants include priority toxic chemicals, organic chemicals, pesticides, non-priority organic chemicals, nutrients, metals, endocrine disruptors, and oxygen-depleting substances.

\subsection{Ground water}

Because of the differences an 'evaluation of ground water quality data is not possible' (US EPA [16], EPA 816-R-98-011, p. 24). Nevertheless a qualitative understanding of the ground water situation 


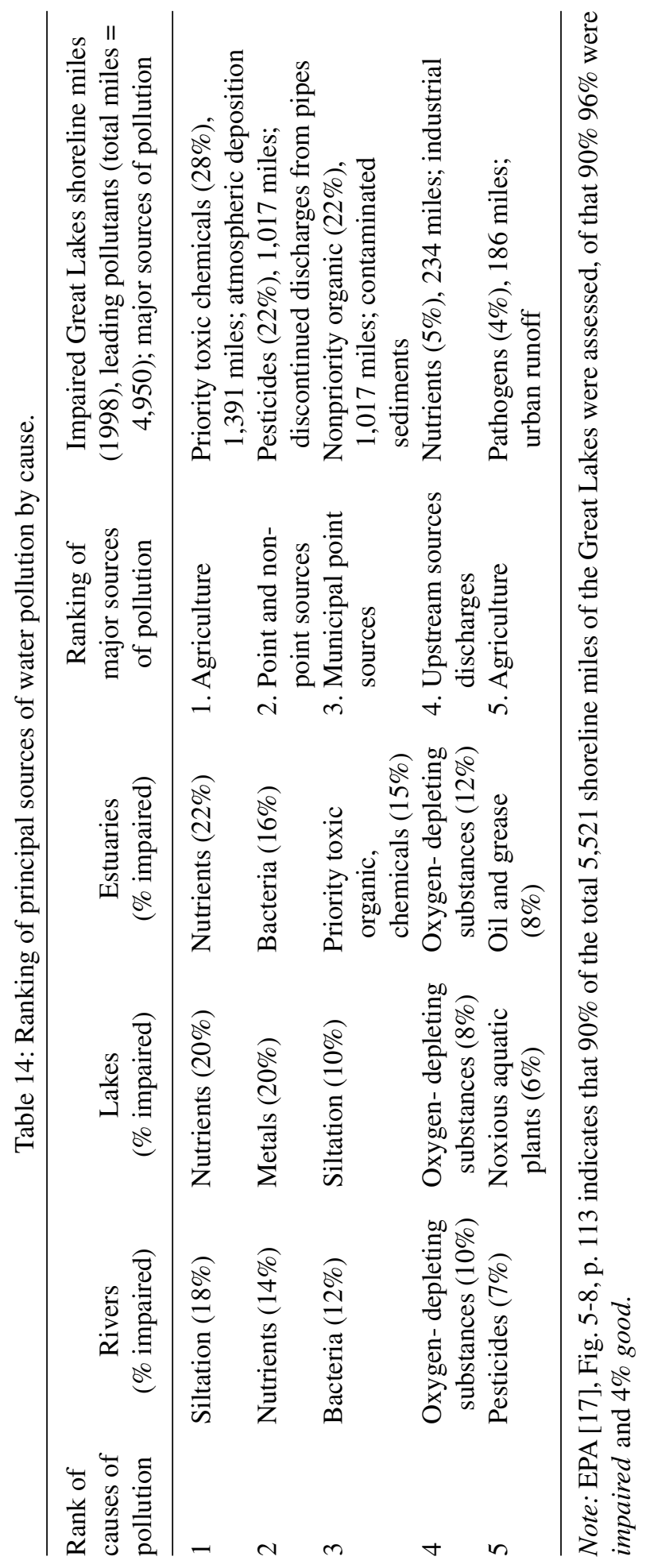


Table 15: Extent of US waters assessed and surveyed, 1996 and 1998 (reported in 1998 and 2000).

\begin{tabular}{lccl}
\hline Rivers and streams & Total miles: & (1996) Miles surveyed: & (1998) Miles assessed: \\
& $3,634,152 ;$ & 693,$505 ; 1,116,088 \mathrm{~km}$ & 842,$426 ;$ \\
& $5,848,6001 \mathrm{~km}$ & & $1,355,753 \mathrm{~km}$ \\
Lakes, ponds, reservoirs & Total acres: 41,684, & $(1996)$ Acres surveyed: & $(1998)$ Acres assessed: \\
& $902 ; 168,693 \mathrm{~km}^{2}$ & $16,819,769 ; 68,067 \mathrm{~km}^{2}$ & $17,390,370 ;$ \\
& & & $70,376 \mathrm{~km}^{2}$ \\
Estuaries & Total $\mathrm{mi}^{2} 39,839 ;$ & $(1996) \mathrm{mi}^{2}$ surveyed: 28, & $(1998) \mathrm{mi}^{2}$ assessed: \\
& $103,183 \mathrm{~km}^{2}$ & $819 ; 74,641 \mathrm{~km}^{2}$ & 28,$687 ; 74,300 \mathrm{~km}^{2}$ \\
Ocean shoreline waters & Total miles: 58,585; & $(1996)$ Miles surveyed: & $(1998)$ Miles assessed: \\
& $94,283 \mathrm{~km}$ & 3,$651 ; 5,876 \mathrm{~km}$ & 3,$130 ; 5,037 \mathrm{~km}$ \\
Great Lakes shorelines & Total miles: 5,521; & $(1996)$ Miles surveyed: & $(1998)$ Miles assessed: \\
& $8,885 \mathrm{~km}$ & 5,$186 ; 8,346 \mathrm{~km}$ & 4,$950 ; 7,966 \mathrm{~km}$
\end{tabular}

Note: The EPA has used different terms (surveyed and assessed) in its reports.

Table 16: 1996 Percentage of individual uses supported by use (Developed from US EPA [15], EPA841-R-97-001).

\begin{tabular}{|c|c|c|c|c|c|c|c|c|c|c|}
\hline \multirow[b]{2}{*}{ Use supported } & \multicolumn{2}{|c|}{$\begin{array}{l}\text { Rivers and } \\
\text { stream }\end{array}$} & \multicolumn{2}{|c|}{$\begin{array}{l}\text { Lakes, ponds } \\
\& \text { reservoirs }\end{array}$} & \multicolumn{2}{|c|}{ Estuaries } & \multicolumn{2}{|c|}{ Great Lakes } & \multicolumn{2}{|c|}{ Ocean shorelines } \\
\hline & $\begin{array}{l}\text { Good } \\
(\%)\end{array}$ & $\begin{array}{l}\text { Fair } \\
(\%)\end{array}$ & $\begin{array}{l}\text { Good } \\
(\%)\end{array}$ & $\begin{array}{l}\text { Fair } \\
(\%)\end{array}$ & $\begin{array}{c}\text { Good } \\
(\%)\end{array}$ & $\begin{array}{l}\text { Fair } \\
(\%)\end{array}$ & $\begin{array}{c}\text { Good } \\
(\%)\end{array}$ & $\begin{array}{l}\text { Fair } \\
(\%)\end{array}$ & $\begin{array}{l}\text { Good } \\
(\%)\end{array}$ & $\begin{array}{l}\text { Fair } \\
(\%)\end{array}$ \\
\hline Aquatic life & 60 & 23 & 55 & 25 & 61 & 27 & 12 & 9 & 91 & 3 \\
\hline $\begin{array}{l}\text { Fish } \\
\text { consumption }\end{array}$ & 84 & 14 & 60 & 32 & 75 & 22 & 2 & 34 & 91 & 5 \\
\hline Swimming & 76 & 10 & 63 & 21 & 83 & 15 & 96 & 3 & 82 & 5 \\
\hline $\begin{array}{l}\text { Secondary } \\
\text { contact }\end{array}$ & 78 & 16 & 62 & 23 & 76 & 22 & 96 & 4 & 93 & 5 \\
\hline $\begin{array}{l}\text { Drinking water } \\
\text { supply }\end{array}$ & 79 & 19 & 81 & 7 & NA & NA & 98 & $<1$ & NA & NA \\
\hline Shell-fishing & NA & NA & NA & NA & 69 & 16 & NA & NA & 84 & 6 \\
\hline Agriculture & 93 & 3 & 84 & 10 & NA & NA & 89 & 11 & NA & NA \\
\hline
\end{tabular}

Note: Good is fully supporting and fair is partially supporting.

Source: US EPA [15], Tables 2-3, 3-3, 4-3, 4-8, and 12-4.

for 1996 (developed from US EPA [16], EPA 816-R-98-011, Table 1, p. 24, 25 and US EPA [17], EPA 841-R-00-001, Table 7-1, p. 170, 171), based on 162 aquifers and other hydrological units in 29 states (26 states in 1998, shown in parentheses) is depicted in Table 20.

Ground water quality is determined from finished water from public water supply wells, PWS wells, $(61 \%)$, untreated water from PWS wells (24\%), monitoring networks (52\%), untreated water from private wells $(36 \%)$, special studies $(6 \%)$, and facility monitoring wells (EPA 816-R-98-011 [16], p. 34, 35, 36, 37, and Fig. 19, p. 32). The water quality parameters include nitrate, VOC, SVOC, bacteria, pesticides ionizing radiation, a number of metals, inorganic compounds, TDS, hardness, 
Table 17: 1998 Percentage of individual water uses supported by use (Developed from US EPA [20], EPA 841-S-00-001).

\begin{tabular}{|c|c|c|c|c|c|c|c|c|c|c|}
\hline \multirow[b]{2}{*}{ Use supported } & \multicolumn{2}{|c|}{$\begin{array}{l}\text { Rivers and } \\
\text { stream }\end{array}$} & \multicolumn{2}{|c|}{$\begin{array}{l}\text { Lakes, ponds } \\
\text { \& reservoirs }\end{array}$} & \multicolumn{2}{|c|}{ Estuaries } & \multicolumn{2}{|c|}{ Great Lakes } & \multicolumn{2}{|c|}{ Ocean shorelines } \\
\hline & $\begin{array}{l}\text { Good } \\
(\%)\end{array}$ & $\begin{array}{l}\text { Fair } \\
(\%)\end{array}$ & $\begin{array}{c}\text { Good } \\
(\%)\end{array}$ & $\begin{array}{l}\text { Fair } \\
(\%)\end{array}$ & $\begin{array}{c}\text { Good } \\
(\%)\end{array}$ & $\begin{array}{l}\text { Fair } \\
(\%)\end{array}$ & $\begin{array}{c}\text { Good } \\
(\%)\end{array}$ & $\begin{array}{l}\text { Fair } \\
(\%)\end{array}$ & $\begin{array}{c}\text { Good } \\
(\%)\end{array}$ & $\begin{array}{l}\text { Fair } \\
(\%)\end{array}$ \\
\hline Aquatic life & 58 & 20 & 58 & 23 & 54 & 29 & 36 & 12 & 87 & 4 \\
\hline $\begin{array}{l}\text { Fish } \\
\text { consumption }\end{array}$ & 87 & 5 & 54 & 35 & 63 & 34 & 4 & 29 & 84 & 10 \\
\hline Swimming & 69 & 11 & 69 & 15 & 88 & 5 & 97 & 2 & 80 & 8 \\
\hline $\begin{array}{l}\text { Secondary } \\
\text { contact }\end{array}$ & 76 & 14 & 78 & 10 & 81 & 15 & 99 & 1 & 93 & 5 \\
\hline $\begin{array}{l}\text { Drinking } \\
\text { water supply }\end{array}$ & 87 & 6 & 82 & 9 & NA & NA & 98 & 0 & NA & NA \\
\hline Shell-fishing & NA & NA & NA & NA & 70 & 14 & NA & NA & 89 & 11 \\
\hline Agriculture & 97 & 2 & 89 & 3 & NA & NA & 100 & 0 & NA & NA \\
\hline
\end{tabular}

Note: Good is fully supporting and fair is partially supporting.

Source: US EPA [20], Figures 3, 6, 9 12, and 15.

Table 18: 1996 and 1998 percent of individual use support in US estuaries (developed from US EPA [15] EPA 841-R-97-008 and US EPA [17] EPA 841-R-00-001).

\begin{tabular}{|c|c|c|c|}
\hline $\begin{array}{l}\text { Use ( } \mathrm{mi}^{2} \text { surveyed), } \\
1996 \text { and } 1998\end{array}$ & $\begin{array}{l}\text { Good (full support) } \\
(\%), 1996 \text { and } 1998\end{array}$ & $\begin{array}{l}\text { Fair (partial support) } \\
(\%), 1996 \text { and } 1998\end{array}$ & $\begin{array}{c}\text { Poor (not supporting) } \\
(\%), 1996 \text { and } 1998\end{array}$ \\
\hline $\begin{array}{c}\text { Aquatic life support, } \\
23,921 \text { and } 22,447\end{array}$ & 61 and 54 & 27 and 29 & 3 and 5 \\
\hline $\begin{array}{l}\text { Fish consumption } \\
15,821 \text { and } 15,260\end{array}$ & 75 and 63 & 22 and 34 & 2 and 1 \\
\hline $\begin{array}{l}\text { Shell-fishing, } \\
16,821 \text { and } 18,212\end{array}$ & 69 and 70 & 16 and 14 & 12 and 13 \\
\hline $\begin{array}{l}\text { Swimming, 24,087 } \\
\text { and } 21,214\end{array}$ & 83 and 88 & 15 and 5 & 1 and 4 \\
\hline $\begin{array}{l}\text { Secondary contact, } \\
14,086 \text { and } 10,503\end{array}$ & 76 and 81 & 22 and 15 & 2 and 1 \\
\hline Geometric average & 72 and 70 & 20 and 16 & 3 and 3 \\
\hline
\end{tabular}

Note: The row percentages may not add to 100 because good (threatened) and poor (not attainable) are not included in this Table; $\mathrm{mi}^{2}$ means square miles.

Sources: Adapted from EPA 841-R-97-008 [15], Fig. 4-3, p. 60 and EPA 841-R-00-001 [17] Fig. 5-2, p. 105. 
Table 19: Aggregated water quality for the United States, 2000 (overall usability as a percent of assessed water, for 47 States).

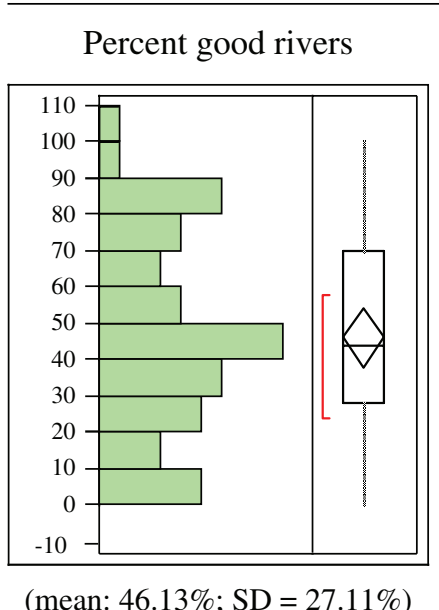

Percent good lakes

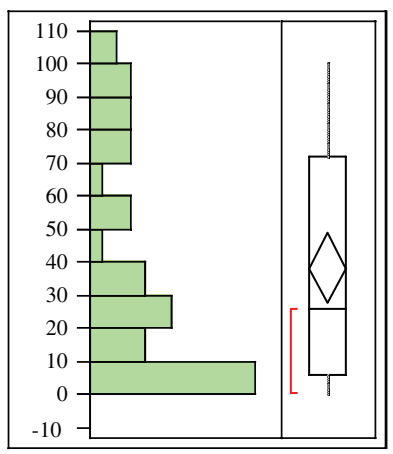

(mean: $38.12 \% ; \mathrm{SD}=34.4 \%$ )

Percent good bays

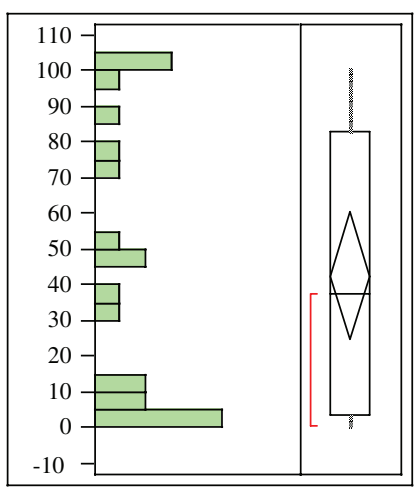

(mean: $42.24 \%$; $\mathrm{SD}=39.25 \%$ )

Percent impaired rivers

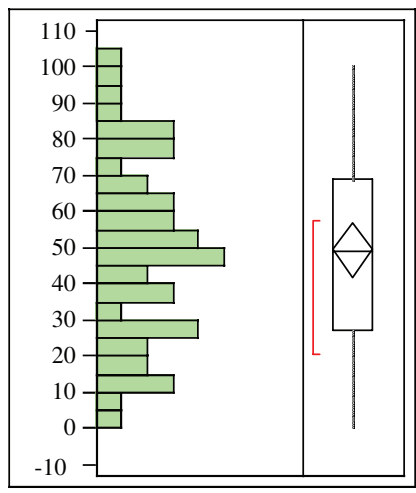

(mean: $49.15 \% ; \mathrm{SD}=26.02 \%$ )

Percent impaired lakes

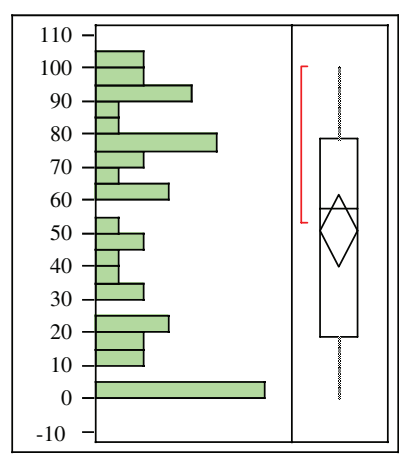

(mean: $50.57 \%$; $\mathrm{SD}=34.86 \%$ )

Percent impaired bays

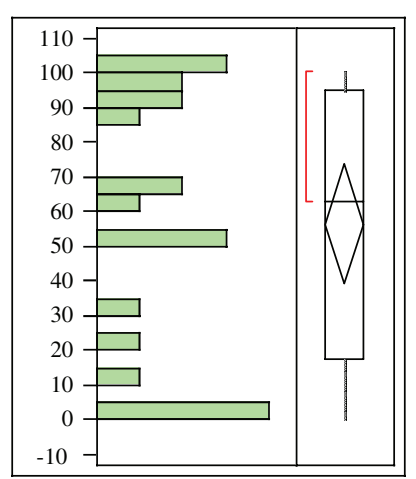

(mean: $56.33 \%$; $\mathrm{SD}=38.36 \%$ )
Percent threatened rivers

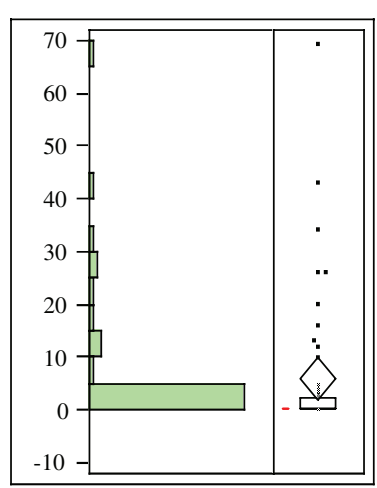

(mean: $5.89 \% ; \mathrm{SD}=13.66 \%$ )

Percent threatened lakes

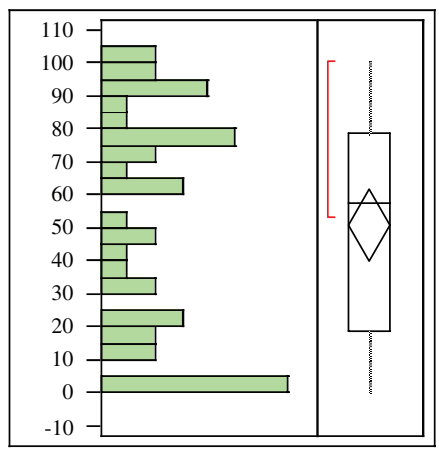

(mean: $10.4 \%$; $\mathrm{SD}=23.75 \%$ )

Percent threatened bays

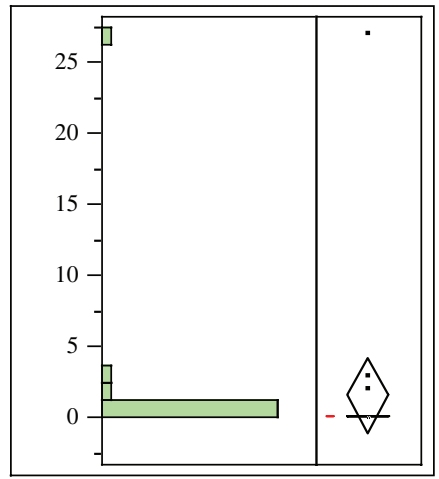

(mean: $1.52 \%$; $\mathrm{SD}=5.89 \%$ ) 
Table 20: Number and Sources of Ground Water Contamination in the US, 1996 and (1998).

\begin{tabular}{|c|c|c|c|c|}
\hline $\begin{array}{l}\text { Sources of } \\
\text { contamination }\end{array}$ & Number of sites & $\begin{array}{l}\text { Sites listed and/or } \\
\text { with confirmed } \\
\text { releases }\end{array}$ & $\begin{array}{l}\text { Sites with confirmed } \\
\text { ground water } \\
\text { contamination }\end{array}$ & $\begin{array}{l}\text { Sites with } \\
\text { completed } \\
\text { cleanup }\end{array}$ \\
\hline Leaking UST & $100,921(85,067)$ & $40,363(48,320)$ & $17,827(15,436)$ & $\begin{array}{c}19,379 \\
(21,438)\end{array}$ \\
\hline $\begin{array}{l}\text { UST sites (no } \\
\text { releases found) }\end{array}$ & $2,210(\mathrm{NR})$ & NA (NR) & NA (NR) & $\mathrm{NA}(\mathrm{NR})$ \\
\hline Septic systems & 10,656 (NR) & 10,594 (NR) & NA (NR) & NA (NR) \\
\hline State sites & $7,017(12,202)$ & $5,751(6,199)$ & $2,614(3,139)$ & $3,166(3,242)$ \\
\hline $\begin{array}{l}\text { Underground } \\
\text { injections }\end{array}$ & $5,006(31,480)$ & $1,077(1,313)$ & $911(172)$ & $204(425)$ \\
\hline $\begin{array}{l}\text { CERCLIS } \\
\text { (CERCLA, non- } \\
\text { NPL) }\end{array}$ & $2,399(3,506)$ & $1,332(1,381)$ & $645(802)$ & 49 (316) \\
\hline $\begin{array}{l}\text { RCRA corrective } \\
\text { action }\end{array}$ & $2,114(2,696)$ & $283(538)$ & $289(267)$ & $52(67)$ \\
\hline DOD and DOE & $404(8,705)$ & $234(4,470)$ & $166(286)$ & $39(1,937)$ \\
\hline Miscellaneous & $229(\mathrm{NR})$ & $905(\mathrm{NR})$ & 514 (NR) & $32(\mathrm{NR})$ \\
\hline Non-point sources & $171(2,030)$ & $190(44)$ & $62(31)$ & $36(3)$ \\
\hline $\begin{array}{l}\text { National priority } \\
\text { list }\end{array}$ & 167 (307) & $250(275)$ & 204 (249) & $24(33)$ \\
\hline Landfills & $149(1,356)$ & $78(110)$ & $74(110)$ & 0 (NA) \\
\hline $\begin{array}{l}\text { wastewater land } \\
\text { application }\end{array}$ & 116 (NR) & NA (NR) & 24 (NR) & $0(\mathrm{NR})$ \\
\hline
\end{tabular}

CERCLIS = Comprehensive Environmental Response, Compensation, and Liability Information System; NA = not available; NR = not reported; RCRA = Resource Conservation and Recovery Act; UST $=$ underground storage tanks.

specific conductivity, alkalinity, nutrients, and so on. Table 21 is a summary of water wells impacted and the rank-ordering of the most significant ground water pollutants, in 1998, at the national level, based on the reporting states.

\subsection{Comment}

Our analyses are at a higher level of detail than the analyses reported by Oki and Kanae [22]. In particular, we do not use hydrological indices, such as the water scarcity index, $\mathrm{R}_{\mathrm{ws}}$, in part because this index is limited by its components (namely, annual water withdrawals, desalinated water, and circulating renewable freshwater) and thus does not account for water quality and for sectoral water withdrawals. Although indices are essential for global comparisons, we believe that the summaries we present in this paper (as well as the more detailed assessments by Ricci and Ricci [23] and Roy et al. [24]) are of sufficient specificity to form a dynamic baseline for planning and for assessing sustainability of water uses in the future. A rough comparison of the results reported by Oki and Kanae [22] for US jurisdictions suggests that the $\mathrm{R}_{\mathrm{ws}}$ for the West is between 0.2 and 1.0; for the East, it is between 0.01 and 0.2. 
Table 21: Wells with number of MCL exceedances (number of states reporting exceedances/total number of states reporting) Rank-ordered by importance (I highest).

\begin{tabular}{|c|c|c|c|c|c|c|}
\hline Monitoring type & I. Nitrates & II. VOCs & III. SVOCs & IV. Pesticides & V. Metals & VI. Bacteria \\
\hline etworks & 267 (8/15) & $30(7 / 10)$ & 5 & $5(2 /$ & $195(7 / 11)$ & $10(1 / 3)$ \\
\hline $\begin{array}{l}\text { PWS untreated } \\
\text { water }\end{array}$ & $85(5 / 7)$ & $77(5 / 6)$ & & & & $1(1 / 1)$ \\
\hline $\begin{array}{l}\text { Private untreated } \\
\text { water }\end{array}$ & $\begin{array}{l}2,233 \\
(9 / 10)\end{array}$ & $96(2 / 3)$ & $4(1 / 3)$ & $101(4 / 5)$ & $113(1 / 1)$ & $0(0 / 1)$ \\
\hline $\begin{array}{l}\text { PWS finished } \\
\text { water }\end{array}$ & $\begin{array}{c}230 \\
(11 / 18)\end{array}$ & $\begin{array}{l}152 \\
(6 / 17)\end{array}$ & $18(3 / 14)$ & $0(0 / 1)$ & $175(4 / 6)$ & $404(3 / 3)$ \\
\hline Special studies & $309(2 / 2)$ & $19(1 / 1)$ & $0(0 / 0)$ & $0(1 / 1)$ & $0(0 / 0)$ & $101(1 / 1)$ \\
\hline
\end{tabular}

Notes: The maximum concentration levels, MCLS, for individual constituents of VOCs, SVOCs, metals, pesticides and bacteria are omitted for brevity's sake. The MCL for nitrates is $10 \mathrm{mg} / \mathrm{lof}$ water.

Source: Tables 3 through to 8, EPA 816-R-98-011 [16], pages 34 though to 39.

By way of interpretation, a $R_{w s}>0.47$ suggests 'highly water stressed' areas. Elsewhere [24] we have used two water indices with more dimensions than a purely hydrological index, and predicted water scarcity or shortages for the United States, at the county level, to approximately 2025, using the coefficient method. In that work, we did not use the IPCC projections, but relied on the US Census Bureau population predictions to assess future water uses. In this work, we focus on existing data, rather than on predictions as those predictions may be greatly affected by geopolitical factors and technologies that are difficult to account for explicitly. Additionally, the impact of climate change on the dynamic baseline we have developed is implicit in the numbers used and is least variable and uncertain relative to prediction for 2050 and 2075 (Oki and Kanae, [22], Fig. 3, Panels A and B). This is not to say that the effects of anthropogenically induced climatic changes are unimportant; quite the opposite: we think that because '[t]he effect of climate change on the hydrological cycles are still uncertain' [22], a semi-quantitative dynamic baseline is essential for water resources planning and management and to assist in meeting the desiderata of sustainability of water uses. In particular, we concur with these authors (p. 1071), who state that 'Climate change is expected to accelerate the global hydrological cycles, and precipitation will increase on average. Evapo-transpiration will not increase as much as precipitation globally because elevated $\mathrm{CO}_{2} \ldots$ reduces evapo-transpiration, and river discharge will increase'.

\section{FACTORS AND FUNCTIONS RELATING TO WATER QUALITY AND QUANTITY}

The factors that affect the predictions of water supply, demand, and quality include:

- Pollution

- Droughts, as increases in frequencies and magnitudes

- Floods, as increases in frequency and magnitude

- Excess water availability, restrictions to access to clean water

- Trans-boundary transfers of water

- Pollution control costs

- Water treatment, including desalination, and other infrastructure 
- Investment costs and timing

- Ecosystems at special risk

- Rehabilitation/restoration of degraded areas

- Food-crop management

- Capacity building for energy supply

- Local, regional, and global climate changes

- Biotechnology applied to crops, livestock, and other uses of crops

- Use of low water consumption crops

- Population growth in urban areas

- Sanitation

- Irrigation changes and efficiencies

- Demand-side management and full pricing of water-related services

- Energy supply and cost

There also are functions that can affect the supply and demand of water; these include:

- Water use conflicts and their resolution

- International effects and implications of non-water-related events

- Policy changes and effects of immigration, employment, subsidies, taxes, or other policies, and

- Changes in the structure of the US economy and in its international partners or competitors

Examples of factors and function, with the ability to reduce water demand and environmental impacts, include:

- Reduced water withdrawals to reduce impact on fish and wildlife, tourism, and navigation

- Reduced water consumption by applying electro-technologies to treat incoming water, reused water, and outgoing wastewater

- Reduced water consumption through operating practices (e.g. water pinch analysis) that streamline the water quality needs (e.g. temperature, chemistry) from one point in a water distribution system to another

- Reduced irrigation withdrawal making more water available to other sectors

- Adoption of economic instruments in the context of increasing water quality, and

- Recharging depleted groundwater aquifers with re-used water.

\section{CONCLUSIONS}

The water situation for the United States is dynamic and is affected by national and international trade, environmental treaties, and conventions (for example NAFTA, Climate Change Treaty, the Kyoto Convention), demographic factors, environmental and energy-related changes, as well as changes in technology, laws, and regulations. The data that we have developed suggests a complex mix of shortand long-term water variability and that structural changes in the (regional and national) economy and socio-economic shifts (such as ageing population) are linked in ways that probably cannot be meaningfully modeled, other than in semi-quantitative ways. The overall description that we have obtained is qualitative: it suggests a relatively good supply of water of good quality from small deviations from the status quo. For example high water prices will occur if the population increases at rates approximating the 'high' Census predictions and if, concomitantly, international demands for US agricultural products change. These increases can affect large segments of the population inequitably. We are also concerned by the potential regional impacts of long-term climate change on the total water picture for the United States. The picture may not be quite as optimistic as some of the predictions discussed suggest. 
The difficulties we have encountered are principally data availability and methodological. We have not studied the national and international institutional, legal, and political aspects of water management, including using economic instruments to control water pollution and their contribution to optimal water resources pricing. Although these impacts are not included in the projections and water budgets reviewed and used in this work, we have developed an information base that can be augmented by these considerations. For example the international demand for agricultural and other US products that strongly depend on water quality and quantity are indirectly accounted for in the water budget and predictions; they should be further assessed relative to future economic changes in the international markets supply and demand. Thus, the agricultural sector is represented in the analyses; however, if the international markets were to deviate significantly from the baseline of the water predictions shown in this work, regional water budget will change accordingly. Understanding local or regional vulnerability of water supply requires a consistent and integrated effort based on empirical and theoretical work necessarily based on modeling. Because of the diversity of jurisdictions, methods used to determine water quality, and changes in both, no between-jurisdictions comparison should be made.

The water quality and quantity monitoring data available to provide the empirical basis for future analyses should be coupled with databases that describe socio-economic, land use, urbanization, ecosystem degradation, and demographic changes. Policy choices affecting water must be resilient to sudden changes and account for the adaptability of ecological systems and the potential for technological innovations, including the potential for unexpected events and outcomes, or responses by stressed systems. Whether or not the overall quality of US waters will approach the $100 \%$ good water quality is difficult to assess but, qualitatively, the overall indications are positive. However, optimisms must be tempered by at least three strong assumptions: (1) regional and global climatic changes will be coped with successfully, (2) the economy will have a rate of growth consistent with its population and productivity growth, and (3) no major catastrophic, either man-made or natural, events will occur in those years.

\section{CONVERSION FACTORS}

Gallons per day $(\mathrm{GPD})=3.785$ liters per day

Million gallons per day $(\mathrm{MGD})=1.121$ thousand acre-feet per year

1 million gallons $(1 \mathrm{MG})=3.07$ acre-feet

1 acre-foot $=325,851$ gallons

Thousand acre-feet per year $=0.8921$ MGD

1 cubic foot $=7.48$ gallons

1 inch of rain $=17.4$ million gallons per square mile

1 inch of rain $=27,200$ gallons per acre

\section{ACKNOWLEDGMENTS}

I thank Dr. Robert Goldstein of EPRI for comments and guidance. This research was in part supported by the Electric Power Research Institute, EPRI, Palo Alto, CA, USA. Much more additional information can be found in [23]. I thank two anonymous reviewers for extensive comment. Dr Tom MacDonald, USF, has also provided very useful comments and checked calculations. 


\section{REFERENCES}

[1] Changnon, S.A. \& Easterling, D.R., US policies pertaining to weather and climate extremes. Science, 289, pp. 2053-2055, 2000.

[2] Easterling, D.R., Meehl, G.A., Parmesan, C., Changnon, S.A., Karl, T.R., \& Mearns, L.O., Climate extremes: observations, modeling, and impacts. Science, 289, pp. 2068-2074, 2000.

[3] Gleick, P.H., Making every drop count. Scientific American, 284, pp. 40-45, 2001.

[4] Postel, S.L., Entering an era of water scarcity: the challenges ahead. Ecological Applications, 10, pp. 941-948, 2000.

[5] U.S. Census Bureau, Annual Projections of the Total Resident Population as of July 1: Middle, Lowest, Highest, and Zero International Migration Series, 1999 to 2100, released January 13, 2000, revised February 14, 2000.

[6] U.S. Census Bureau, Population Projections of the Total Resident Population by Quarter: Middle Series, April 1, 1999 to January 1, 2101, released January 13, 2000.

[7] Solley, W.B., Pierce, R.R., \& Perlman, H.A., Estimated Uses of Water in the United States in 1995, USGS Circular 1200, Washington DC, 1998.

[8] US Environmental Protection Agency, President Clinton's Clean Water Initiative (A.K.A. The Green Book), EPA 800-R-94-001, Office of Water: Washington, DC, 1994.

[9] Solley, W.B., Water-use estimates in the United States 1950-95, with projections to 2040. USGS, Reston VA, 2000.

[10] Brown, T.C., Projections of U.S. freshwater withdrawals. J. Wat. Res. Res., 36, pp. 769-780, 2000.

[11] Trimble, S.W. \& Crosson, P., US soil erosion rates - myth and reality, Science, 289, pp. 248-250, 2000.

[12] Brown, T.C., Past and Future Freshwater Use in the United States, US Dept. of Agriculture, Forest Service tech rep. RMS-GTR-39, 1999.

[13] US Environmental Protection Agency, Environmental Investments: the costs of a clean environment, EPA 230-11-90-083, EPA Office of Policy, Planning and Evaluation, Nov. 1990.

[14] US Environmental Protection Agency, National Water Quality Inventory: 1988 Report to Congress, EPA 440-4-90-003, Office of Water, Washington, DC, 1990.

[15] US Environmental Protection Agency, The Quality of Our Nation's Water: 1996, EPA 841-S97-001, Office of Water, Washington, DC, 1998.

[16] US Environmental Protection Agency, National Water Quality Inventory: 1996 Report to Congress, Groundwater Chapters, EPA 816-R-98-011, Office of Water, Washington, DC, 1998.

[17] US Environmental Protection Agency, National Water Quality Inventory: 1998 Report to Congress, EPA 841-R-00-001, Office of Water, Washington, DC, 2000.

[18] Vorosmarty, C.J., Green, P., Salisbury, J., \& Lammers, R.B., Global water resources: vulnerability from climate change and population growth. Science, 289, pp. 284-288, 2000.

[19] Guldin, R.W., An Analysis of the Water Situation in the United States: 1989-2040, Ge. Tech Rep. RM 177, Rocky Mountain Forest and Range Experimental Station: Fort Collins, CO, 1989.

[20] US Environmental Protection Agency, The Quality of Our Nation's Waters: a summary of the National Water Quality Inventory: 1998 Report to Congress, EPA 841-S-00-001, Office of Water, Washington, DC, 2000.

[21] US EPA, http://www.epa.gov/wayers/395b, 2004.

[22] Oki, T. \& Kanae, S., Global hydrological cycles and world water resources. Science, 313, pp. 1068-1072, 2006. 
[23] Ricci, P.F. \& Ricci, L.E., Water \& Sustainability (Vol. 2): An Assessment of Water Demand, Supply, and Quality in the US - The Next Half Century, EPRI: Palo Alto, CA, 2002.

[24] Roy, S.B., Ricci, P.F., Summers, K.V., Chung, C.-F. \& Goldstein, R.A., Evaluation of the sustainability of water withdrawls in the United States, 1995 to 2025. J. Am. Water Res. Assoc., 41(5), pp. 1091-1108, 2005. 